\title{
FUEL LEAN BIOMASS REBURNING IN COAL-FIRED BOILERS
}

\author{
Final Technical Report
}

Reporting Period Start Date: July 1, 2000

Reporting Period End Date: June 30, 2002

Principal Author(s):

Jeffrey J. Sweterlitsch and Robert C. Brown

Date Report Issued:

July, 2002

DOE Award Number:

DE-FG26-00NT40811

Submitted By:

Center for Sustainable Environmental Technologies

Iowa State University

285 Metals Development Bldg.

Ames, IA 50011-3020 


\section{DISCLAIMER}

This report was prepared as an account of work sponsored by an agency of the United States Government. Neither the United States Government nor any agency thereof, nor any of their employees, makes any warranty, express of implied, or assumes any legal liability or responsibility for the accuracy, completeness, or usefulness of any information, apparatus, product, or process disclosed, or represents that its use would not infringe privately owned rights. Reference herein to any specific commercial product, process, or service by trade name, trademark, manufacturer, or otherwise does not necessarily constitute or imply its endorsement, recommendation, or favoring by the United States Government or any agency thereof. The views and opinions of authors expressed herein do not necessarily state or reflect those of the United States Government or any agency thereof. 


\section{ABSTRACT}

This final technical report describes research conducted between July 1, 2000, and June 30, 2002, for the project entitled "Fuel Lean Biomass Reburning in Coal-Fired Boilers," DOE Award No. DE-FG26-00NT40811. Fuel Lean Biomass Reburning is a method of staging fuel within a coal-fired utility boiler to convert nitrogen oxides (NOx) to nitrogen by creating locally fuel-rich eddies, which favor the reduction of NOx, within an overall fuel lean boiler. These eddies are created by injecting a supplemental fuel source, designated as the reburn fuel, downstream of the primary combustion zone. Chopped biomass was the reburn fuel for this project.

Four parameters were explored in this research: the initial oxygen concentration ranged between $1 \%-6 \%$, the amount of biomass used as the reburn fuel ranged between from $0 \%-$ $23 \%$ of the total \% energy input, the types of biomass used were low nitrogen switchgrass and high nitrogen alfalfa, and the types of carrier gases used to inject the biomass (nitrogen and steam). Temperature profiles and final flue gas species concentrations are presented in this report. An economic evaluation of a potential full-scale installation of a Fuel-Lean Biomass Reburn system using biomass-water slurry was also performed. 


\section{TABLE OF CONTENTS}



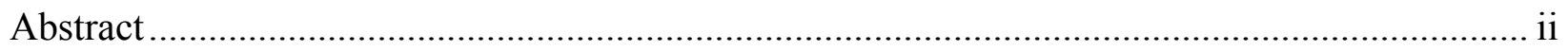

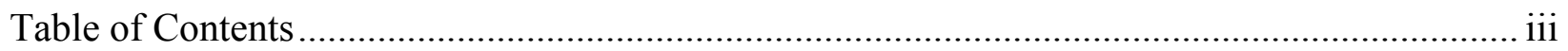

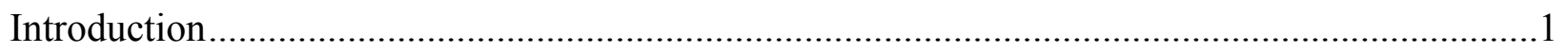

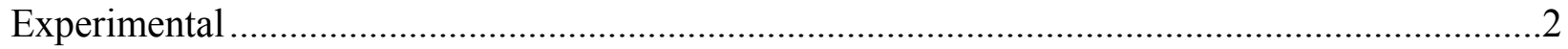

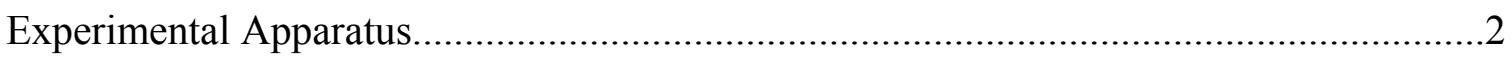





Preliminary Carrier Gas Experiments ...........................................................................11

Carbon Dioxide Tracer Experiments ...........................................................................17

Fuel-Lean Biomass Reburning Experiments .............................................................19



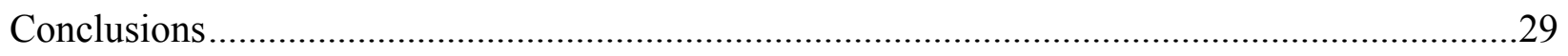

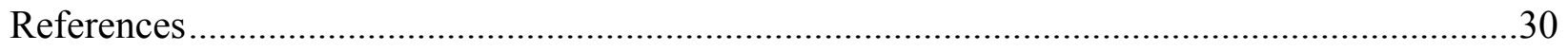




\section{INTRODUCTION}

Fuel-lean Gas Reburning is a method of controlling $\mathrm{NO}_{\mathrm{x}}$ emissions produced during coal combustion in utility boilers by injecting natural gas into the boiler downstream of the primary combustion zone. Whereas traditional reburning requires $10 \%-20 \%$ of the total energy input from the reburn fuel followed by over-fire air to complete combustion of fuel fragments, FuelLean Gas Reburning uses only $5 \%-10 \%$ of the total energy input from the reburn fuel. Because less fuel is used, the overall environment in the boiler remains fuel lean, with only localized eddies that are fuel-rich, where the $\mathrm{NO}_{\mathrm{x}}$ reduction takes place. Fuel-Lean Gas Reburning does not require over-fire air to complete the combustion of fuel fragments. Fuel-Lean Biomass Reburning is a variation of Fuel-Lean Gas Reburning that uses biomass instead of natural gas as the reburn fuel.

The goal of this work was to simulate two types of coal-fired utility boilers in an experimental down-flow reactor in evaluating the effectiveness of two types of biomass as reburn fuels. An economic analysis of a potential full-scale installation was also performed.

The small scale of the down-flow reactor was not capable of simulating a full-scale boiler because in a full-scale boiler there would be significant radial species concentration gradients, temperature gradients, and a much higher degree of turbulence. The experimental simulations performed in this research focus on the reburning process that occurs within turbulent eddies, and does not simulate the mixing that would occur downstream of fuel-rich and fuel-lean eddies. As explained above, Fuel-Lean Reburning uses on 5\% - $10 \%$ of the total energy input, averaged across the entire boiler volume. Within some turbulent eddies, however, the \% energy input for a given volume of flue gas can and does exceed $10 \%$ energy input. Many experiments performed in the laboratory use more than 10\% energy input from biomass as the reburn fuel.

Pulverized coal boilers and stoker boilers were simulated by varying the amount of air that was reacted: lower flow rates of air, producing initial $\mathrm{O}_{2}$ concentrations of $1 \%, 2 \%, 3 \%$, and $4 \%$, represented pulverized coal boilers, while higher flow rates of air, producing initial $\mathrm{O}_{2}$ concentrations of $5 \%$ and $6 \%$, represented stoker boilers. Stoker boilers typically have shorter residence times and lower operating temperatures, and increasing the air flow rate produces both conditions simultaneously within the experimental down-flow reactor.[1] The primary fuel for the down-flow reactor was not coal, but natural gas. Natural gas combustion does not produce as much nitric oxides as coal combustion, so a small amount of anhydrous ammonia $(0.45 \%$ by volume of the total gaseous fuel input) was introduced into the natural gas line to artificially increase the initial $\mathrm{NO}_{\mathrm{x}}$ concentrations, approaching those of coal combustion.

The two types of biomass used were low nitrogen-containing switchgrass and high nitrogencontaining alfalfa. By comparing a high nitrogen-containing biomass fuel with a low nitrogencontaining biomass fuel, it could be determined if there was any amine-enhancement during the reburning process.[2] Injecting the biomass into the down-flow reactor was done pneumatically, using nitrogen and/or steam. By using steam it is proposed that the biomass would gasify in situ, generating more volatiles to react with the $\mathrm{NO}_{\mathrm{x}}$. 


\section{EXPERIMENTAL WORK}

\section{Experimental Apparatus}

The down-flow reactor consists of a natural gas burner, an insulated reaction chamber where the reburning process occurs, and a flue gas exhaust system. The natural gas burner is a Kromschroder, Inc., BIC50 nozzle-mixed burner nominally rated at $35 \mathrm{~kW}$. The burner consists of a cast-iron housing, a stainless steel burner manifold where the air and natural gas mix, and a 0.305 m. (12 in.) long silicon carbide burner tube, which completes the combustion of the natural gas. Figure 1 shows the burner mounted on top of the reactor. The insulated reaction chamber consists of seven separate sections of reactor that can be arranged in several configurations. Each section consists of a $0.152 \mathrm{~m}$. (6 in.) diameter opening insulated by $0.229 \mathrm{~m}$. (9 in.) thick castable ceramic, enclosed by a $9.53 \mathrm{~mm}$. (0.375 in.) thick steel shell. Figure 2 shows the configuration employed in this current research. Also shown in Figure 2 is the biomass hopper and the water jacket to cool the exhaust.

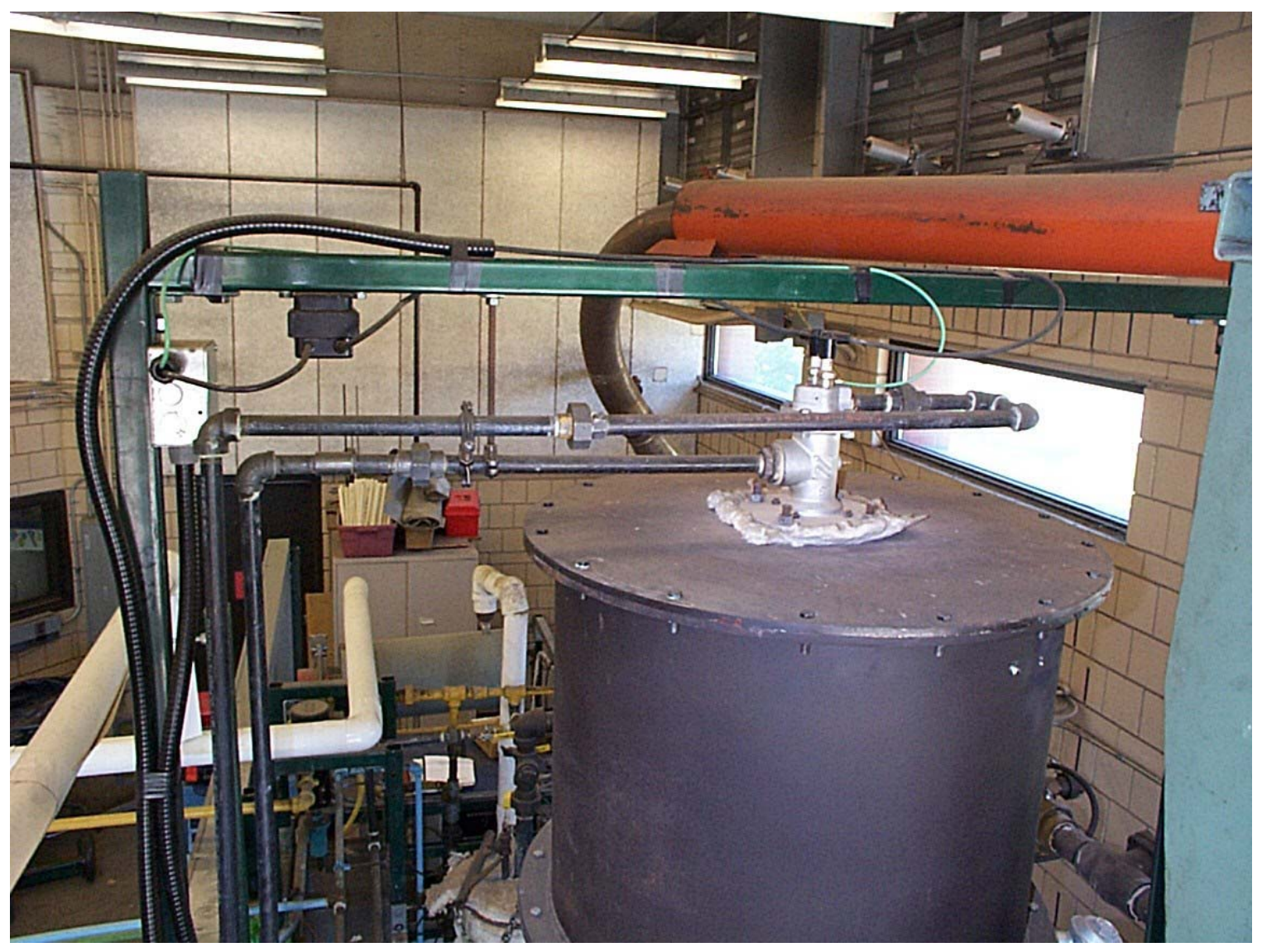

Figure 1. Natural gas burner.

Figure 3 is of the main control panel. On this control panel the primary air and natural gas flow rates are controlled with rotameters and measured with digital flow meters. Also controlled on this panel are the water flow rate for the water jacket, the carrier gas flow rate for biomass injection, and the ammonia flow rate, which is used for doping the natural gas with ammonia to produce $\mathrm{NO}_{\mathrm{x}}$ emissions. The large enclosure shown on the right of this photograph contains the 
automatic controller for the natural gas burner. There is also a power switch to turn on/off the biomass hopper. The flow rate of the biomass hopper is set by a dial located next to the biomass hopper.

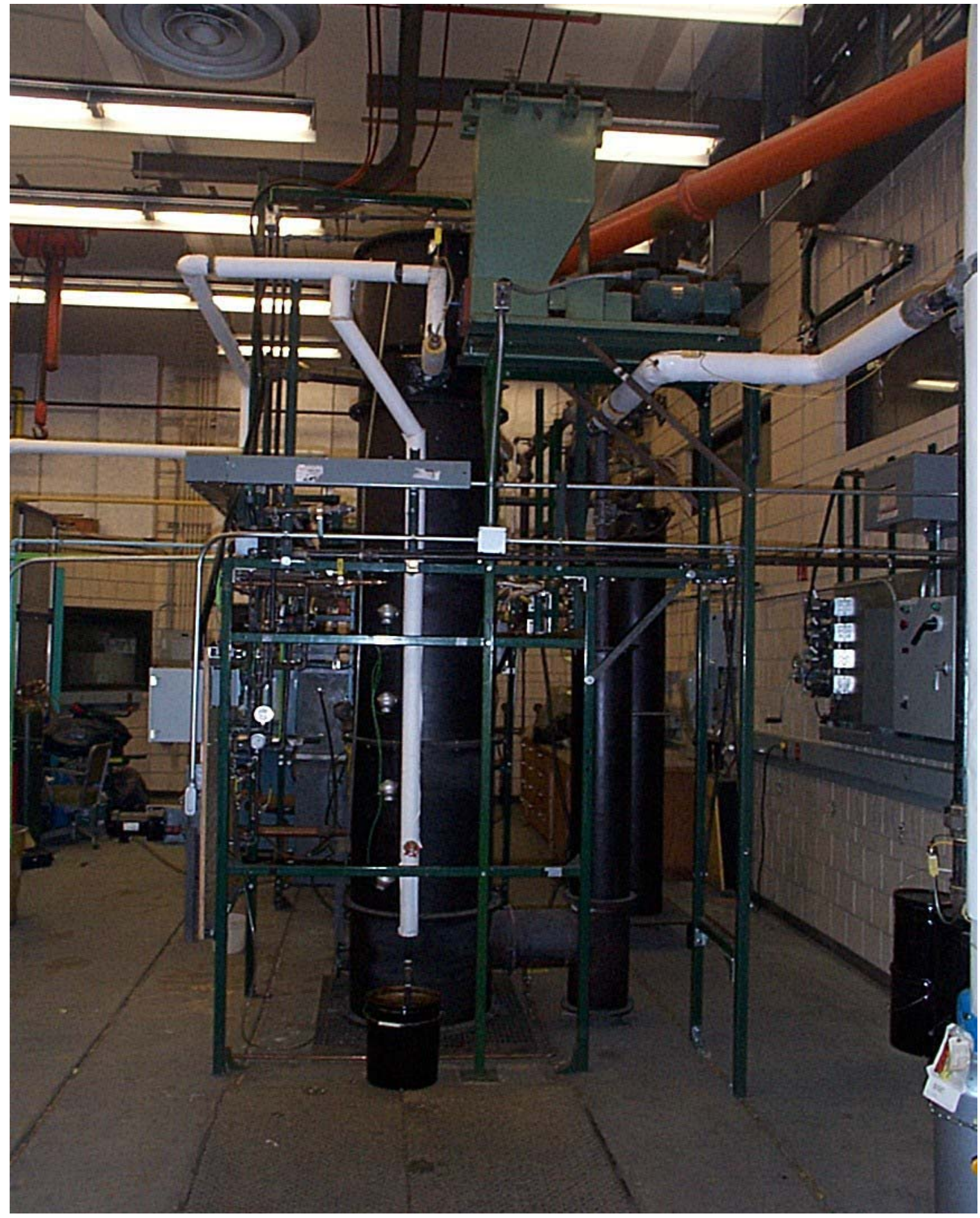

Figure 2. Down-flow reactor with biomass hopper, steam drain, and water jacket. 


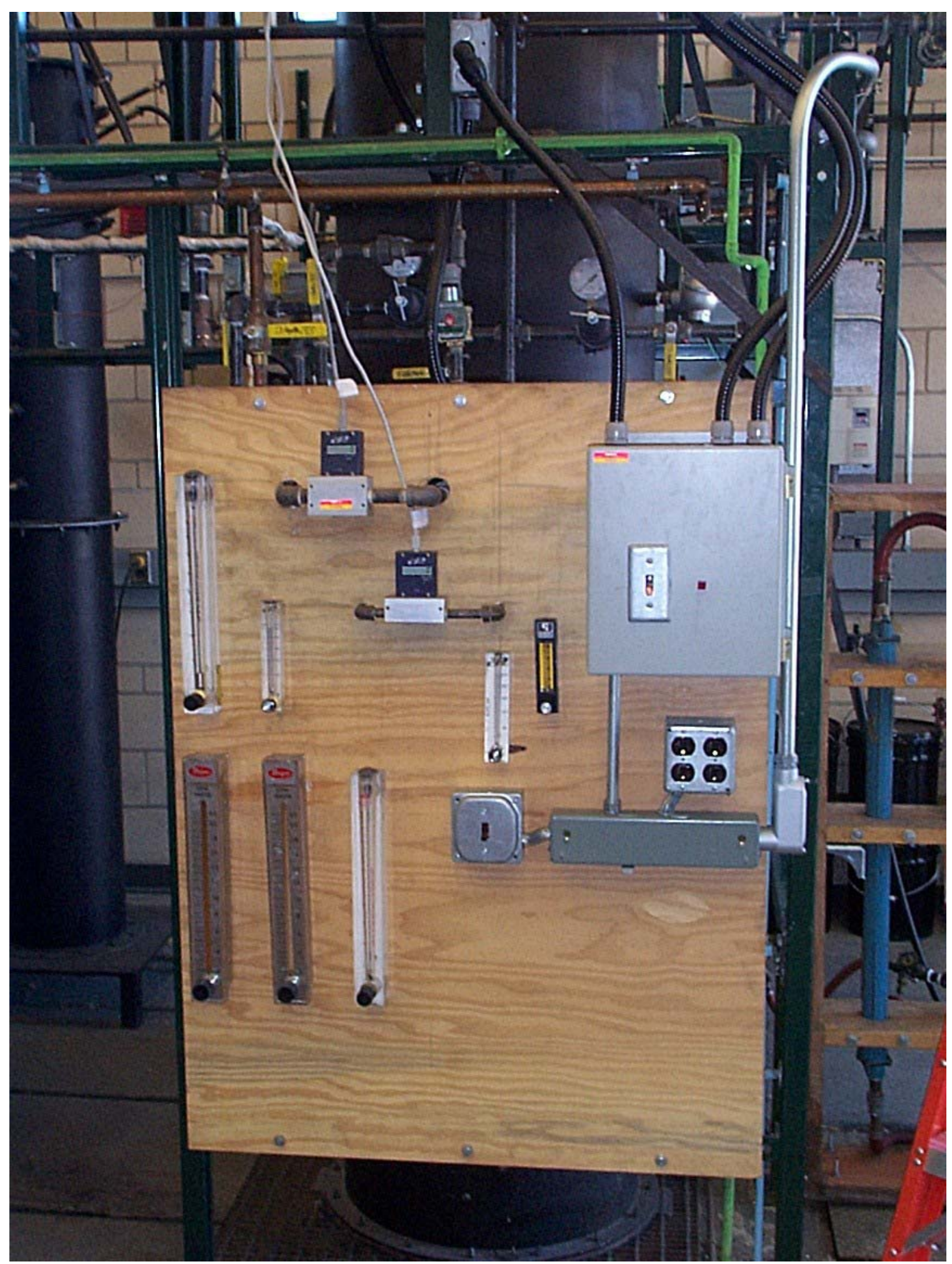

Figure 3. Main control panel. 


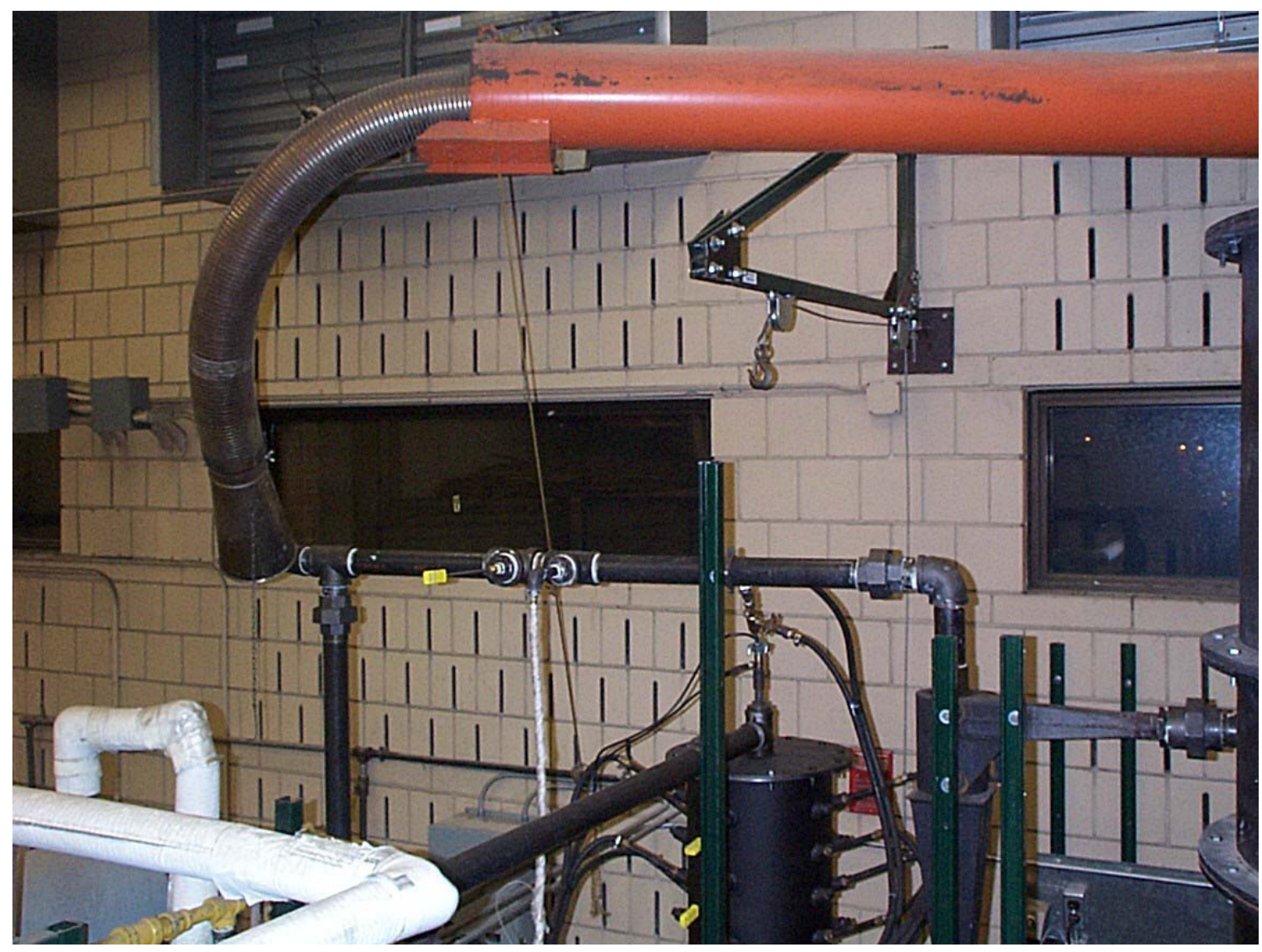

Figure 4. Cyclone, fifth sampling port, and exhaust.

Figure 4 shows how the exhaust from the down-flow reactor is vented from the laboratory. After the process stream leaves the water jacket, it enters a cyclone, pictured on the right of Figure 4, then by the fifth sampling, shown in the middle of Figure 4, and finally is vented to an ceiling fan that exhausts the process stream from the laboratory.

The biomass injection port underwent several modifications. Figure 5 shows the final arrangement. The two most challenging issues were to prevent flue gas in the reactor from entering the biomass hopper and to prevent steam and biomass from forming wet clumps of biomass, which clogged the injection lines. Originally, steam was to be the only carrier gas for the biomass, but it was determined that too much steam was flowing into the biomass hopper, even when the hopper was sealed. (A perfect seal was never obtained.) Also, the steam was not superheated sufficiently after being throttled through a needle valve to prevent condensation in the horizontal plumbing. Finally, the quantity of steam required to physically transport the biomass from the hopper into the reactor resulted in a significant temperature decrease within the reaction chamber. Mixtures of nitrogen and steam were attempted as transporting gases, but with limited success. The arrangement shown in Figure 5 relies solely on nitrogen as the carrier gas; steam was introduced separately. 


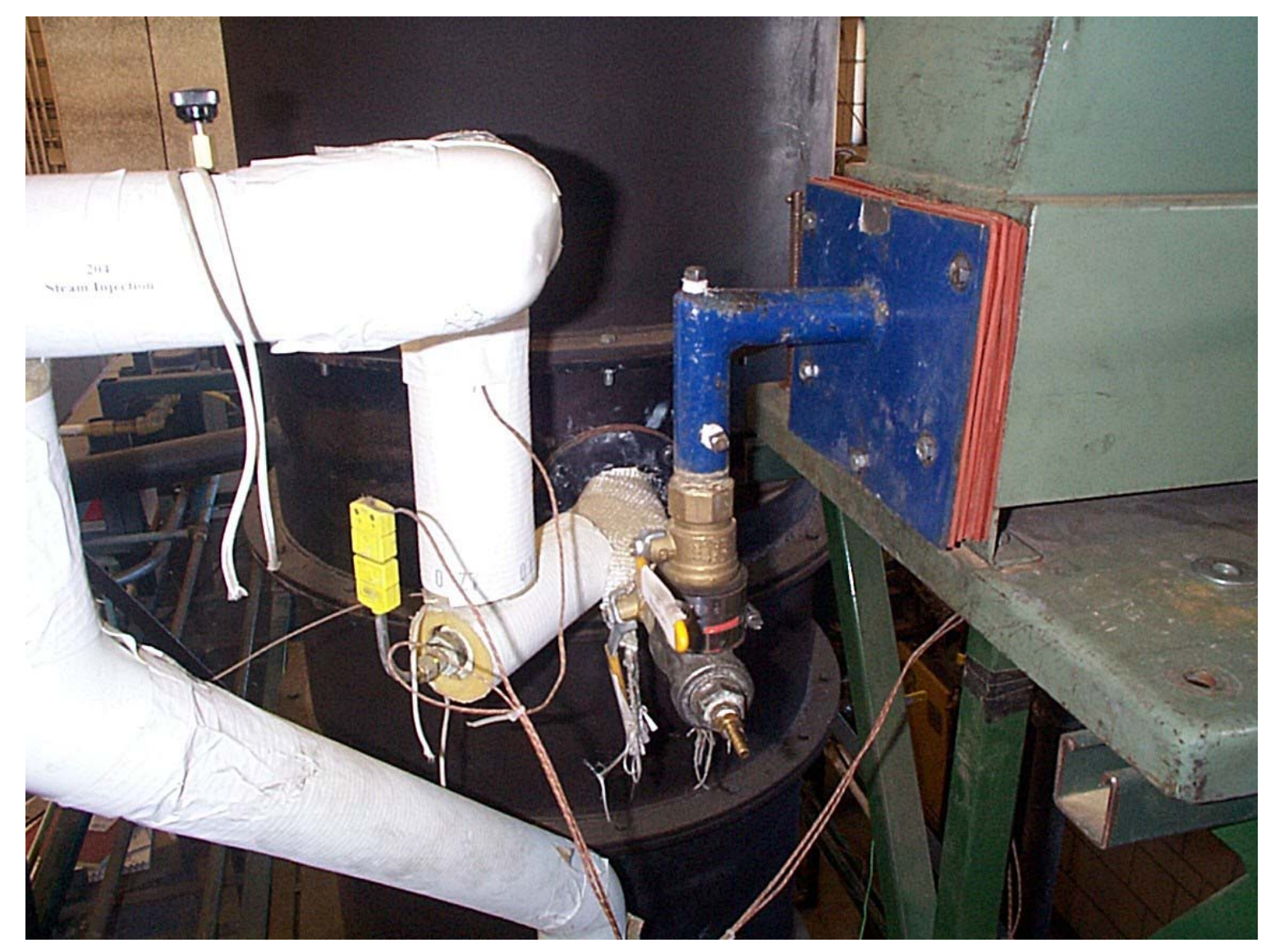

Figure 5. Biomass injection port with steam addition.

Figure 6 shows the four main sampling port of the main reaction chamber. The first sampling port is located $1.71 \mathrm{~m}$. (67.5 in.) from the top of the reactor, or $1.08 \mathrm{~m}$ (42.5 in) from the biomass injection port. The residence time from the biomass injection port to this sampling port is estimated to be 0.36 seconds, assuming no biomass or carrier gas is being used. The sampling following three sample port are located $0.38 \mathrm{~m}$ (15 in) apart. The estimated residence time at the fourth sampling port is 0.81 seconds. The sample line is made of stainless steel tubing and is electrically heated to prevent condensation.

Figure 7 shows the continuous emission gas analyzers, contained in what is referred to as the gas cart. In addition to four separate analyzers, there is a particulate filter, an acid-mist filter, and a PermaPure membrane dryer to condition the gas samples for the analyzers. Oxygen is measured with a California Analytical, Inc., Model 100F Electrochemical Fuel Cell analyzer. Carbon monoxide and carbon dioxide are measured with a California Analytical, Inc., ZRH-2 non-dispersed infrared analyzer. Nitric oxide and nitrogen dioxide are measured in a Thermo Environmental Model 42C-HL chemilumenescient analyzer that is capable of report oxides of nitrogen as $\mathrm{NO}, \mathrm{NO}_{2}$, and $\mathrm{NO}_{\mathrm{x}}$. Also in this gas cart is a sulfur dioxide analyzer, although it was not used in this research. All data from the analyzers, as well as from all thermocouples and the digital flow meters, are recorded using National Instruments data acquisition equipment and Labview software. 


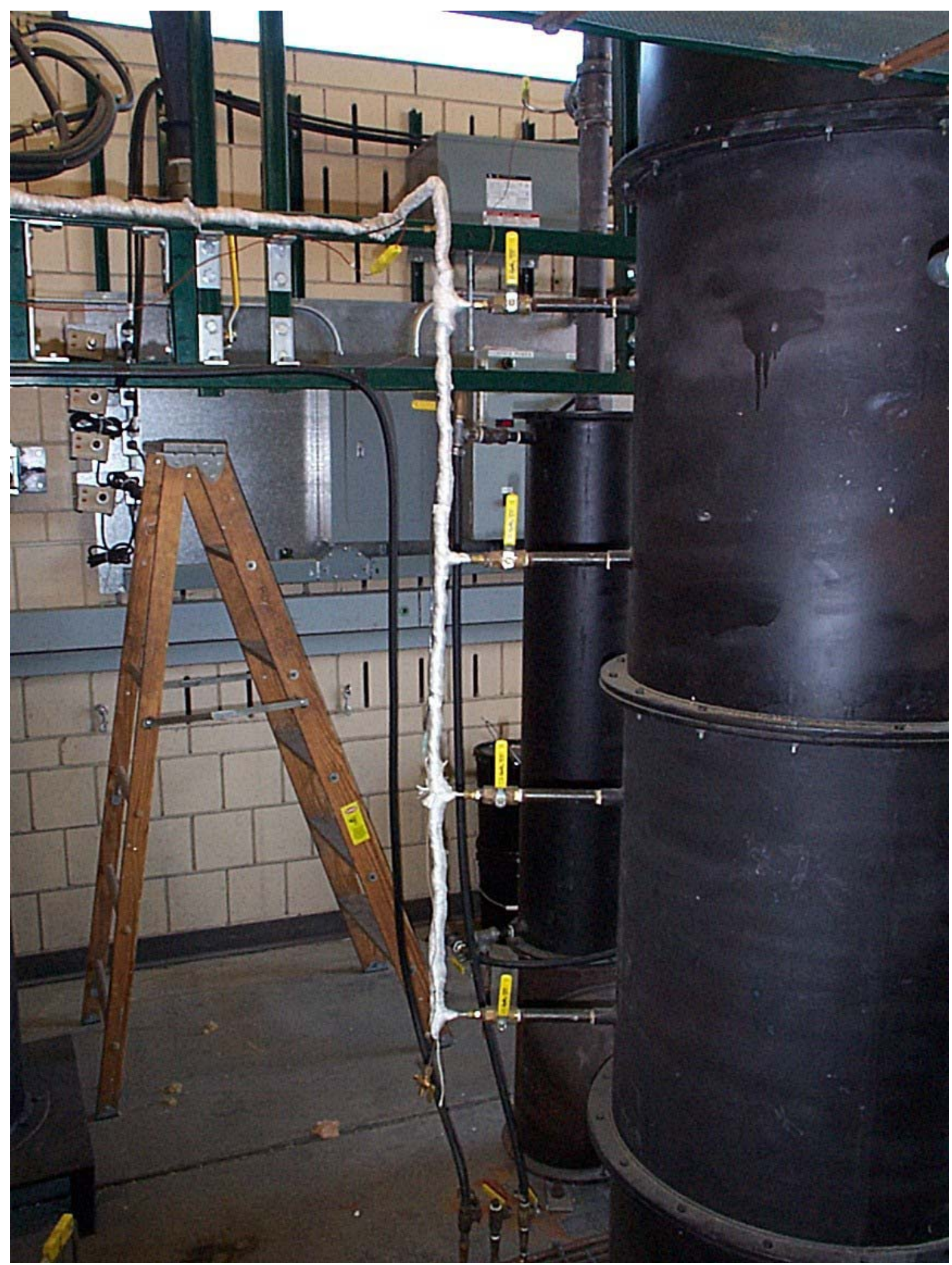

Figure 6. Main sampling ports. 


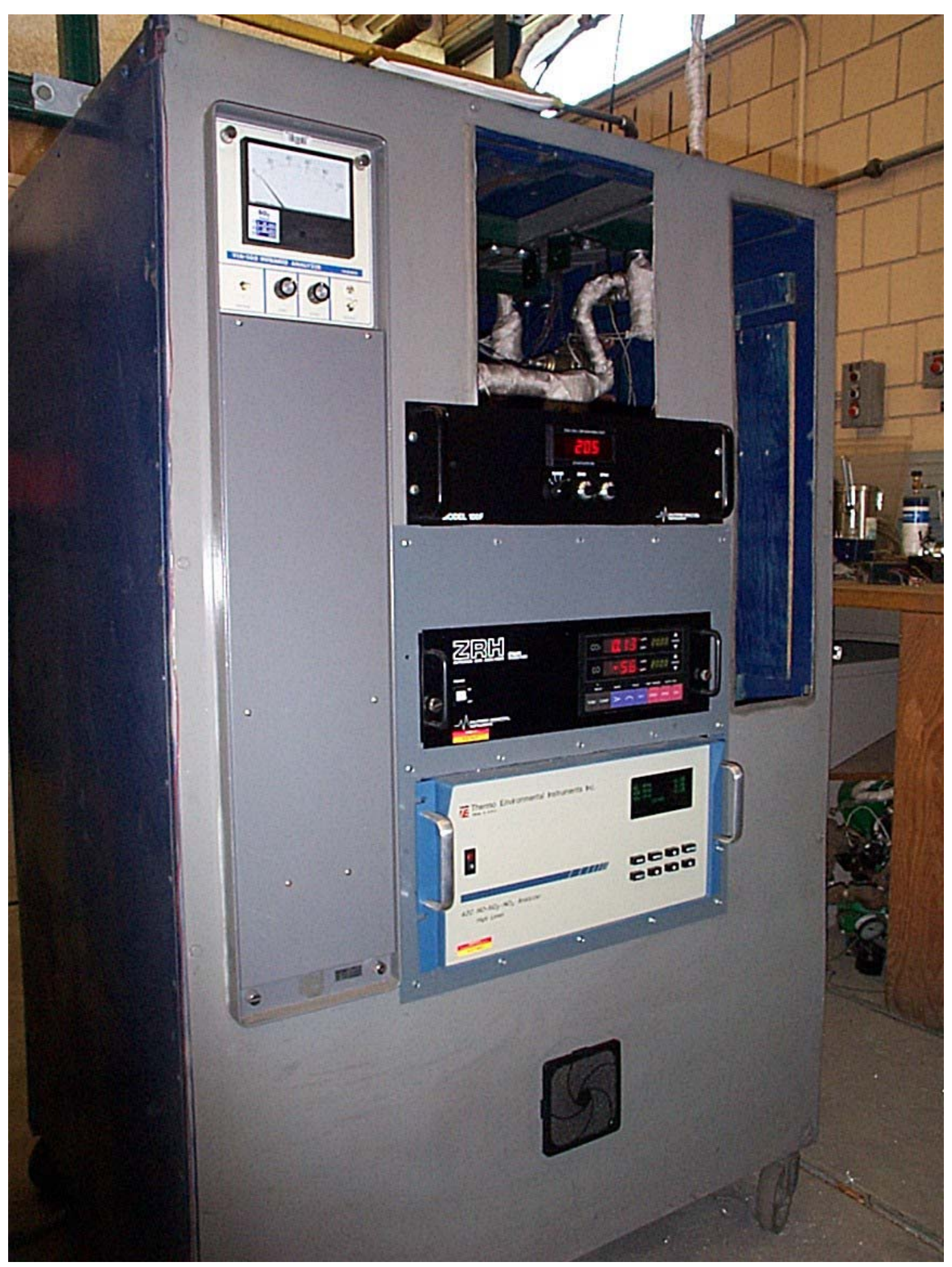

Figure 7. Gas cart that houses all gas analyzers. 


\section{Summary of Experiments}

Four parameters were investigated for this research: 1) the type of carrier gas used, either steam or nitrogen; 2) the amount of biomass used, based on heating value of the biomass; 3 ) the type of biomass used, either low-nitrogen containing switchgrass or high-nitrogen containing alfalfa; and 4) the initial concentration of oxygen in the flue gas.

A preliminary set of experiments were developed to determined if there would be sufficient mixing of the flue gas with the biomass in the down-flow reactor. Supplementary calculations determined that the Reynolds number within the reactor varied from approximately 2900, near the top of the reactor, to 4300 , near the bottom of the reactor. These values indicate only slightly turbulent flow, so there was concern that there may be insufficient mixing between the volatiles coming from the biomass particles and the flue gas. Tracer experiments with carbon dioxide were performed to determine if there were any axial concentration gradients. Radial concentration gradients were not explicitly investigated. Experiments were performed under both hot and cold (room temperature) conditions. At room temperature conditions, lower flow rates of air were required to achieve Reynolds numbers that were comparable to values achieved in the combustor when it was operated hot.

To determine the effect of different carrier gases on flue gas composition, a series of experiment were conducted by injecting nitrogen or steam into the reactor without biomass. These tests were important to make sure that subsequent reburning tests with biomass were substantially due to the biomass and not the carrier gas. The combustor was allowed to thermally stabilize during five days of operation. Cylinders of nitrogen were connected to the auxiliary carrier gas rotameter, described previously with Figure 3. Different flow rates of nitrogen were injected into the down-flow reactor through the biomass injection port, and the axial temperature was measured.

To determine the effect of steam addition, a method of injecting a known flow rate of steam was required. Steam available in the laboratory is saturated at $627 \mathrm{kPa}$ (91 psi). To control the flow rate of steam, a precision metering needle valve was installed in the steam line upstream of the biomass injection port. Just upstream of this valve was a branch in the line that allowed the steam to bleed off into a container. This limited the amount of condensation that may collect in the steam line upstream of the needle valve. As the steam exits the needle valve, it is throttled, resulting in superheated, but cooler, steam. A condensing heat exchanger was connected to the steam line to calibrate the steam flow rate, basing the flow rate on the number of complete revolutions of the precision metering needle valve. Zero, two, three, four and five complete turns of the metering valve were tested.

The parameters explored in the reburning experiments included $\%$ energy input from biomass, the initial oxygen concentration in the flue gas, and the type of biomass used. The \% energy input was varied from $4.2 \%-23.0 \%$. The initial oxygen concentration in the flue gas varied from $1.05 \%-6.35 \%$. Two types of biomass were used, switchgrass and alfalfa. Switchgrass represents a low nitrogen-containing biomass reburn fuel, while alfalfa represents a high nitrogen-containing biomass reburn fuel. The chemical compositions and thermal analyses of switchgrass and alfalfa are presented in Table 1. The particle size distribution of ground switchgrass is shown in Figure 8, and the particle size distribution of ground alfalfa is shown in Figure 9. 
Table 1. Chemical and thermal analysis of switchgrass and alfalfa.

\begin{tabular}{|l|c|c|c|c|}
\hline \multirow{2}{*}{} & \multicolumn{2}{|c|}{ Switchgrass } & \multicolumn{2}{c|}{ Alfalfa } \\
\cline { 2 - 5 } & Dry & As Received & Dry & As Received \\
\hline \multicolumn{1}{|c|}{ Proximate } & & & & \\
\hline$\%$ ash & $3.80 \%$ & $3.60 \%$ & $8.45 \%$ & $7.72 \%$ \\
\hline$\%$ moisture & & $4.10 \%$ & & $8.62 \%$ \\
\hline \% volatile matter & $82.60 \%$ & $79.20 \%$ & $77.80 \%$ & $71.09 \%$ \\
\hline \% fixed carbon & $13.60 \%$ & $13.10 \%$ & $13.76 \%$ & $12.57 \%$ \\
\hline \multicolumn{1}{|c|}{ Ultimate } & & & & \\
\hline$\%$ ash & $3.80 \%$ & $3.60 \%$ & $8.45 \%$ & $7.72 \%$ \\
\hline \% carbon & $44.23 \%$ & $42.40 \%$ & $45.95 \%$ & $41.98 \%$ \\
\hline$\%$ hydrogen & $5.07 \%$ & $5.32 \%$ & $6.01 \%$ & $6.45 \%$ \\
\hline$\%$ nitrogen & $0.64 \%$ & $0.61 \%$ & $2.92 \%$ & $2.67 \%$ \\
\hline$\%$ sulfur & $0.09 \%$ & $0.09 \%$ & $0.16 \%$ & $0.15 \%$ \\
\hline$\%$ oxygen & $46.17 \%$ & $47.98 \%$ & $35.52 \%$ & $41.03 \%$ \\
\hline MJ / kg & 18.13 & 17.38 & 18.72 & 17.11 \\
(BTU / lb) & $(7793)$ & $(7470)$ & $(8050)$ & $(7356)$ \\
\hline
\end{tabular}

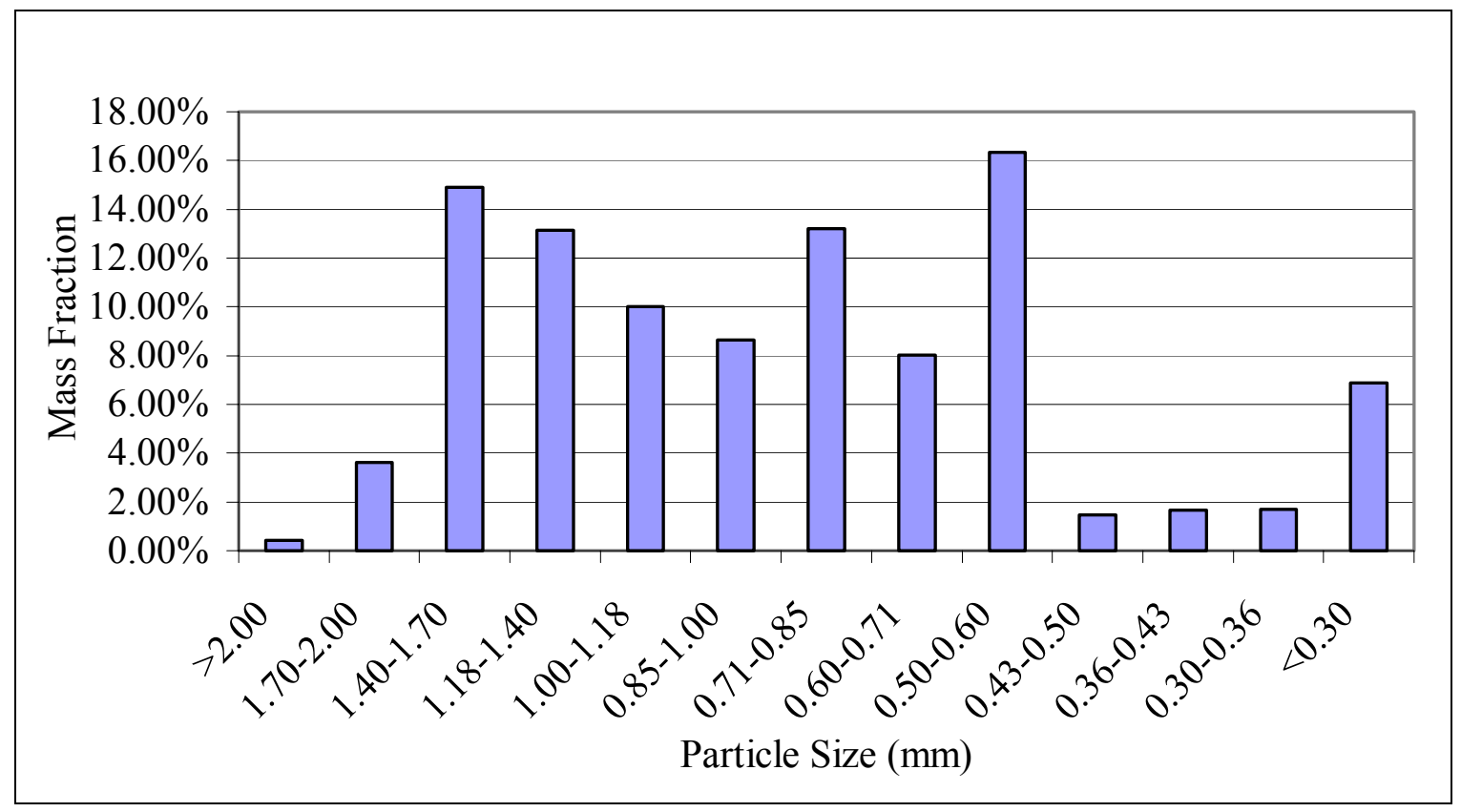

Figure 8. Particle size distribution of ground switchgrass. 


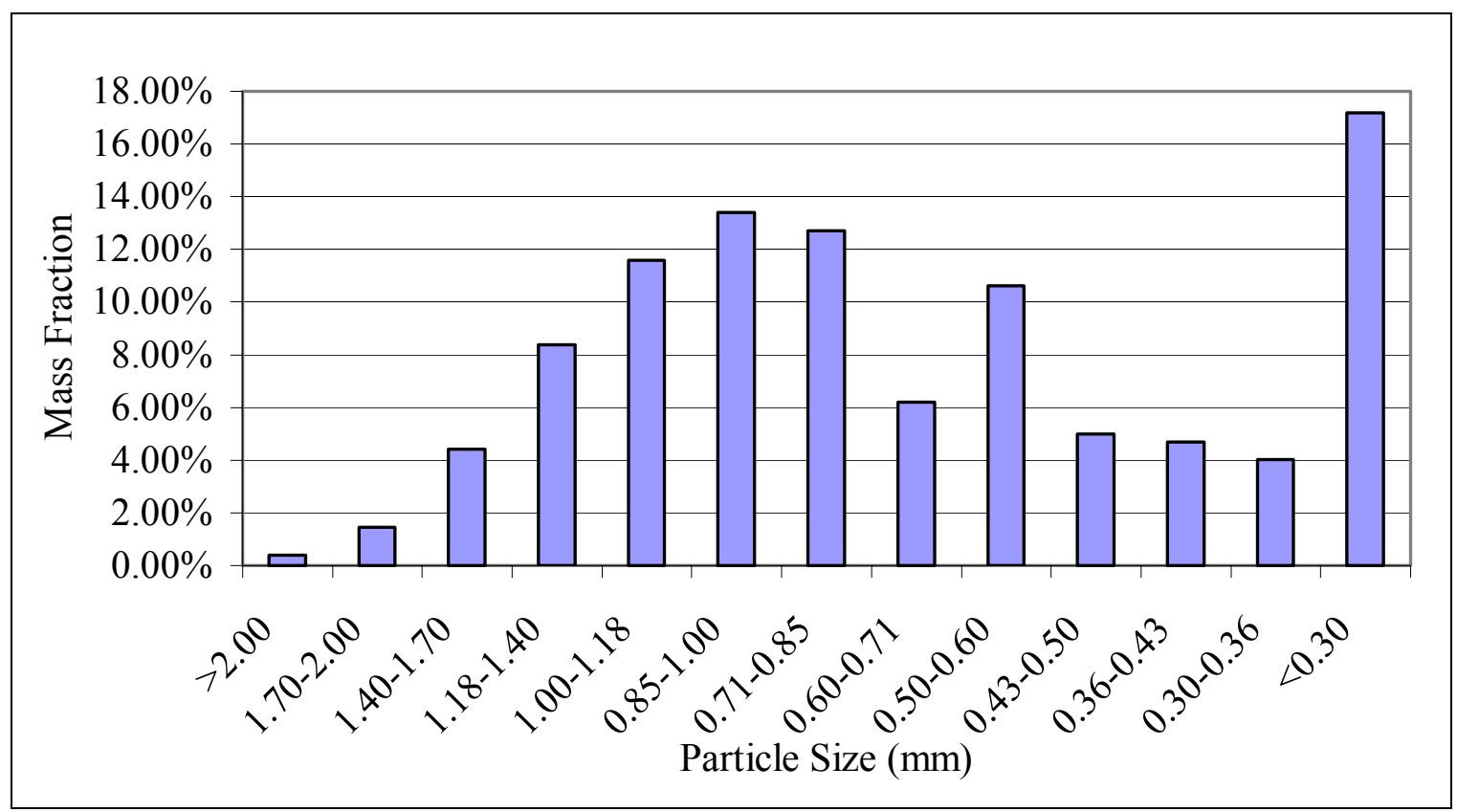

Figure 9. Particle size distribution of ground alfalfa.

\section{RESULTS AND DISCUSSION}

\section{Preliminary Carrier Gas Experiments}

Table 2 summarizes the parameters investigated in the first set of experiments performed, which were designed to determine the effect of nitrogen and steam injection on the initial gas species concentrations. Both nitrogen and steam were introduced into the reactor through the biomass injection port.

$\mathrm{NO}_{\mathrm{x}}, \mathrm{CO}_{2}$, and $\mathrm{O}_{2}$ concentrations were measured at the exhaust. Figures $10-12$ show the exhaust concentrations of $\mathrm{NO}_{\mathrm{x}}, \mathrm{CO}_{2}$, and $\mathrm{O}_{2}$, respectively. For $\mathrm{NO}_{\mathrm{x}}$ and $\mathrm{CO}_{2}$, the only effect of nitrogen injection is dilution. The concentration of $\mathrm{O}_{2}$, however, remained constant, and no dilution was apparent. Figure 13 is the axial temperature profile, measured at locations downstream relative to the biomass injection port, for different flow rates of nitrogen. There was a slight decrease in temperature with increasing amounts of nitrogen, and the profiles become less steep with greater amounts of injected nitrogen. It should be noted that $37.8 \mathrm{liter} / \mathrm{min}$ of nitrogen injected into the reactor is equivalent to $5.5 \%$ of the total mass flow rate in the reactor. For Experiments 13 - 85, however, 47.2 liter/min of nitrogen were required to successfully inject biomass into the reactor, but it is believed that additional nitrogen will only dilute the process stream further without changing the chemistry within the reactor. Error bars in all figures represent the $95 \%$ confidence interval.

Figures $14-16$ show the exhaust concentrations of $\mathrm{NO}_{\mathrm{x}}, \mathrm{CO}_{2}$, and $\mathrm{O}_{2}$, respectively. In all cases, there was no effect of steam addition, nor any dilution of the analyzed gas stream. This is because the gas conditioning PermaPure membrane dryer removed moisture from the gas sample before it is analyzed. Figure 17 is the axial temperature profile, measured at locations downstream relative to the biomass injection port, for different flow rates of steam. At first 
steam injection appears have a much greater effect on the axial temperature profile that the nitrogen, but it should be noted that $0.11 \mathrm{~kg} / \mathrm{min}$ of steam is equivalent to $12.6 \%$ of the total mass flow rate within the reactor, which is considerably higher than the $5.5 \%$ of the total mass flow rate describe earlier for the nitrogen injection experiments.

Table 2. Preliminary carrier gas eperiments test matrix.

\begin{tabular}{|c|c|c|}
\hline Experiment & $\begin{array}{c}\text { Nitrogen Flow Rate } \\
\text { liter / min (SCFH) }\end{array}$ & $\begin{array}{c}\text { Steam Flow Rate } \\
\mathrm{gm} / \mathrm{min}\end{array}$ \\
\hline \hline 1 & 0 & 0 \\
\hline 2 & $18.9(40)$ & 0 \\
\hline 3 & $28.3(60)$ & 0 \\
\hline 4 & $37.8(80)$ & 0 \\
\hline 5 & 0 & 45 \\
\hline 6 & 0 & 68 \\
\hline 7 & 0 & 93 \\
\hline 8 & 0 & 107 \\
\hline
\end{tabular}

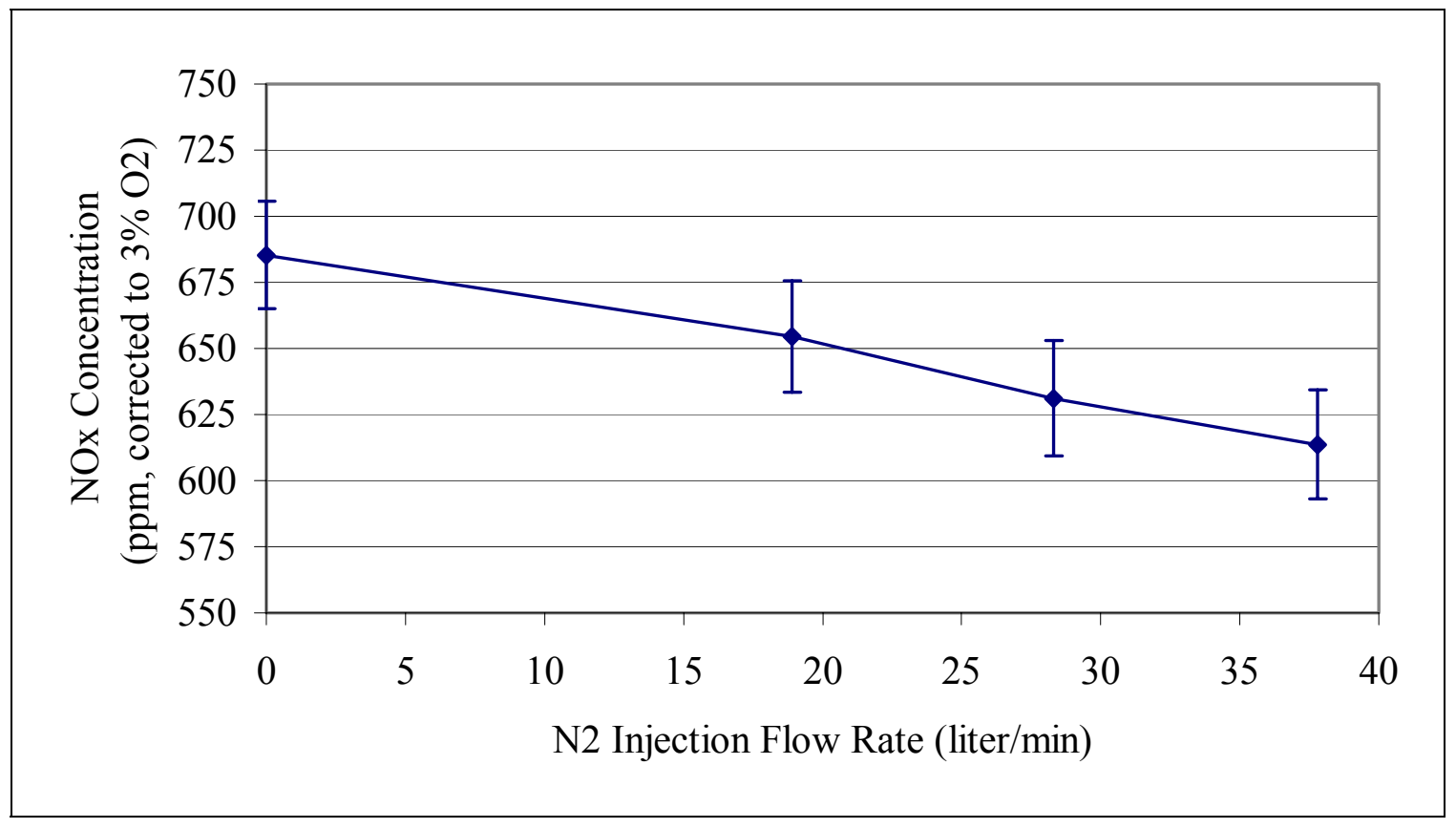

Figure 10. Effect of $\mathrm{N}_{2}$ injection on $\mathrm{O}_{2}$ concentration measured at the exhaust. 


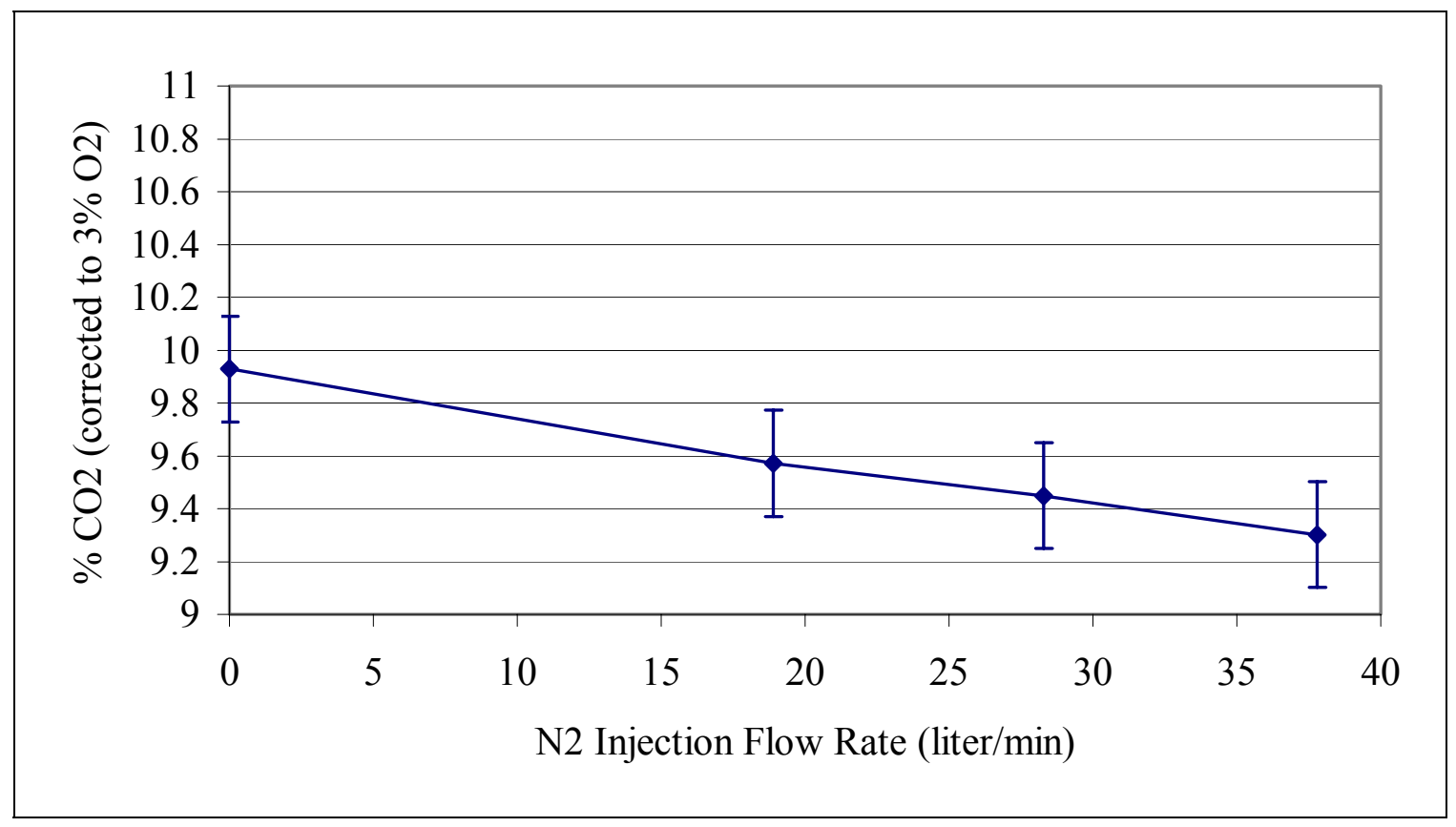

Figure 11. Effect of $\mathrm{N}_{2}$ injection on $\mathrm{CO}_{2}$ concentration measured at the exhaust.

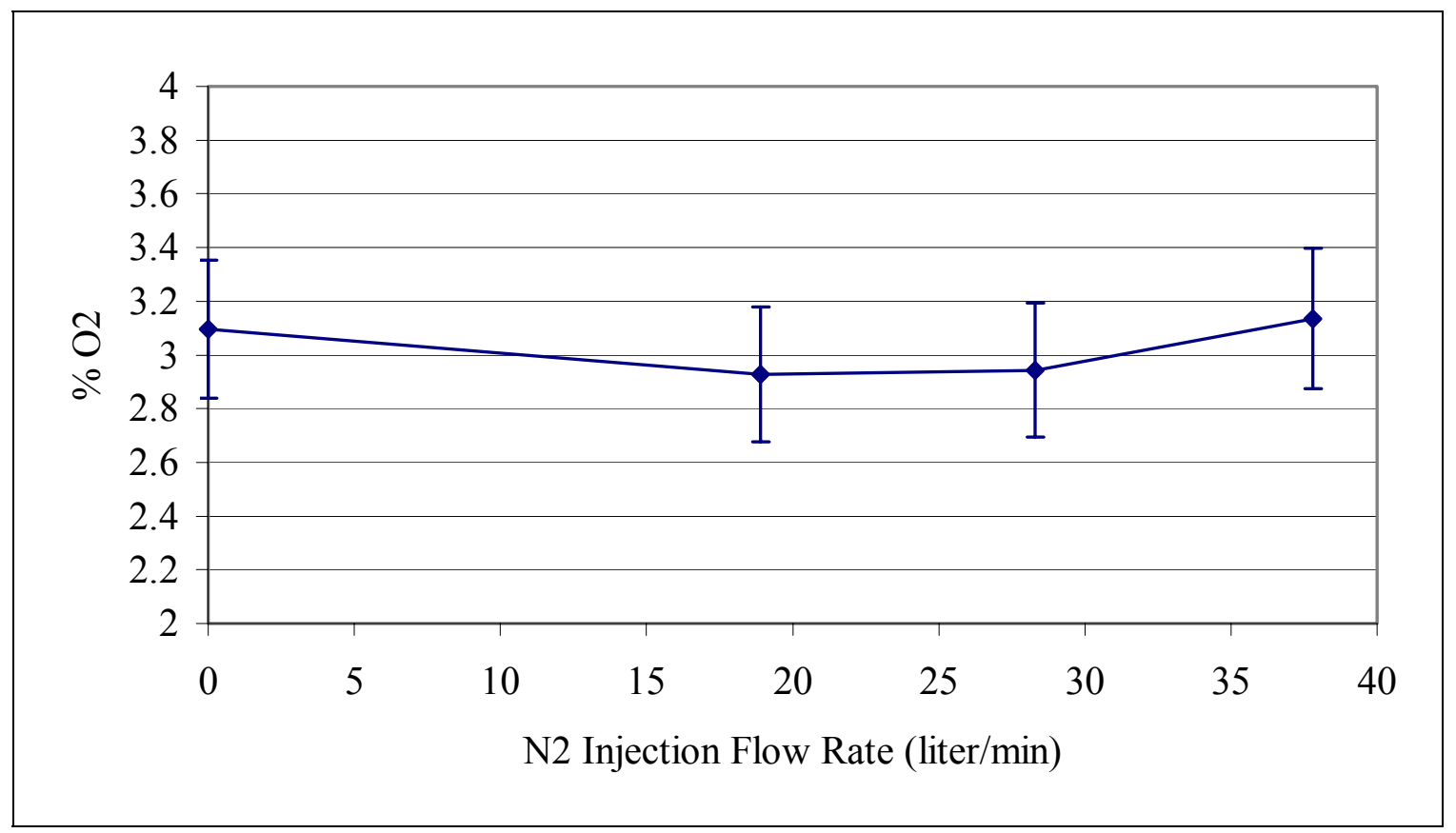

Figure 12. Effect of $\mathrm{N}_{2}$ injection on $\mathrm{O}_{2}$ concentration measured at exhaust. 


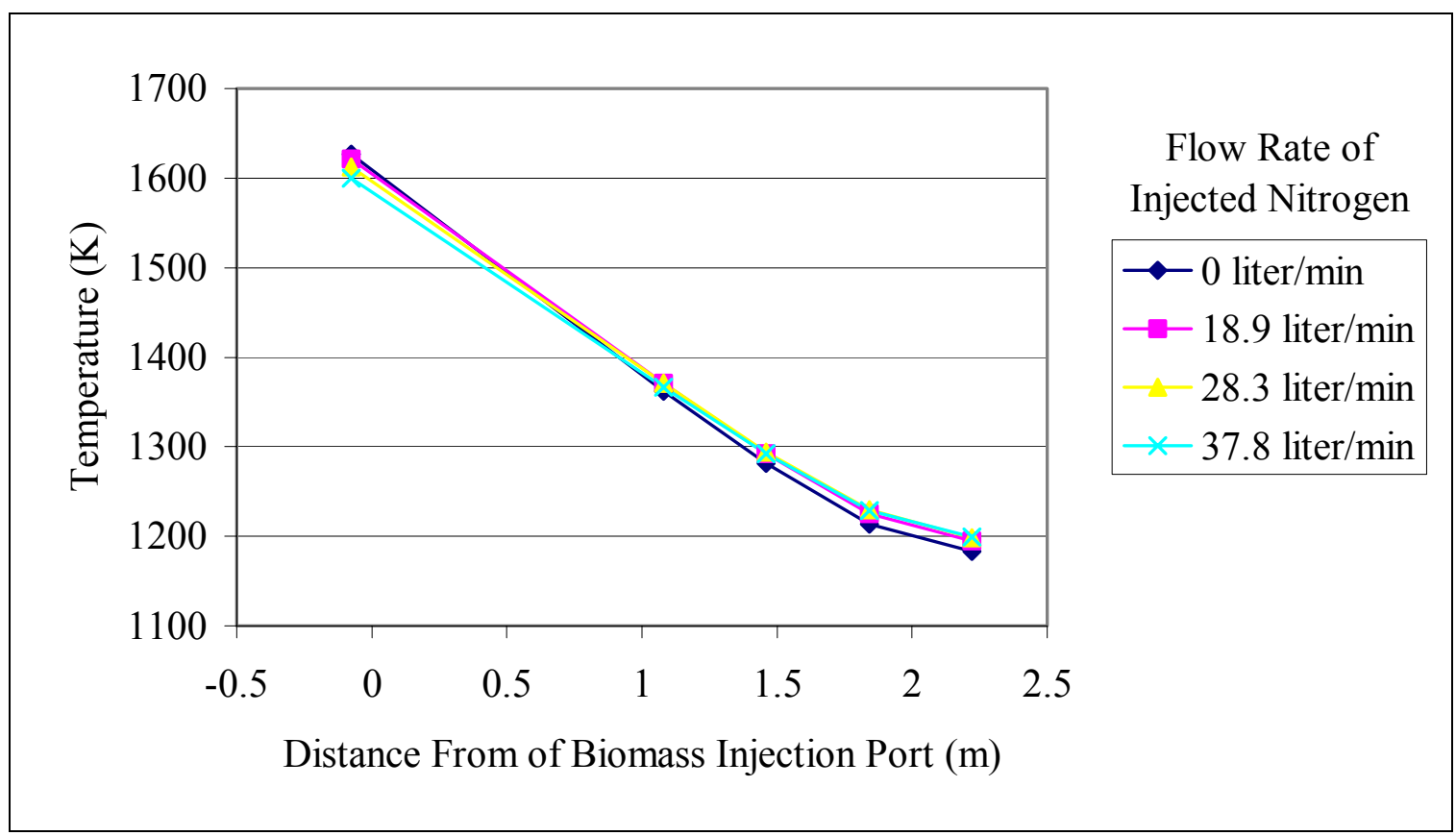

Figure 13. Axial temperature profiles vs. distance downstream from the biomass injection port. No biomass was injected.

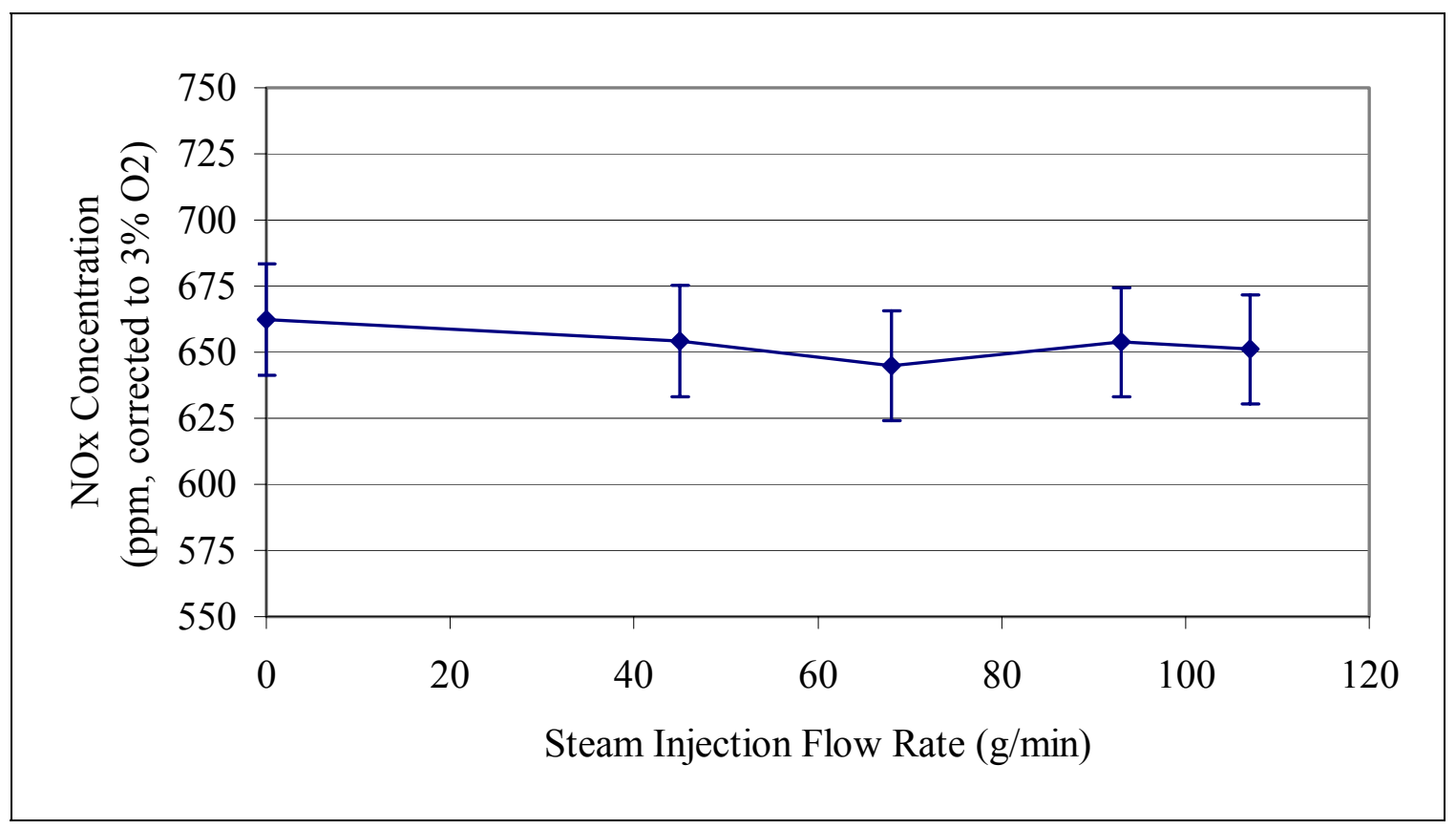

Figure 14. Effect of Steam Injection on the $\mathrm{NO}_{\mathrm{x}}$ Concentration Measured at the Exhaust. 


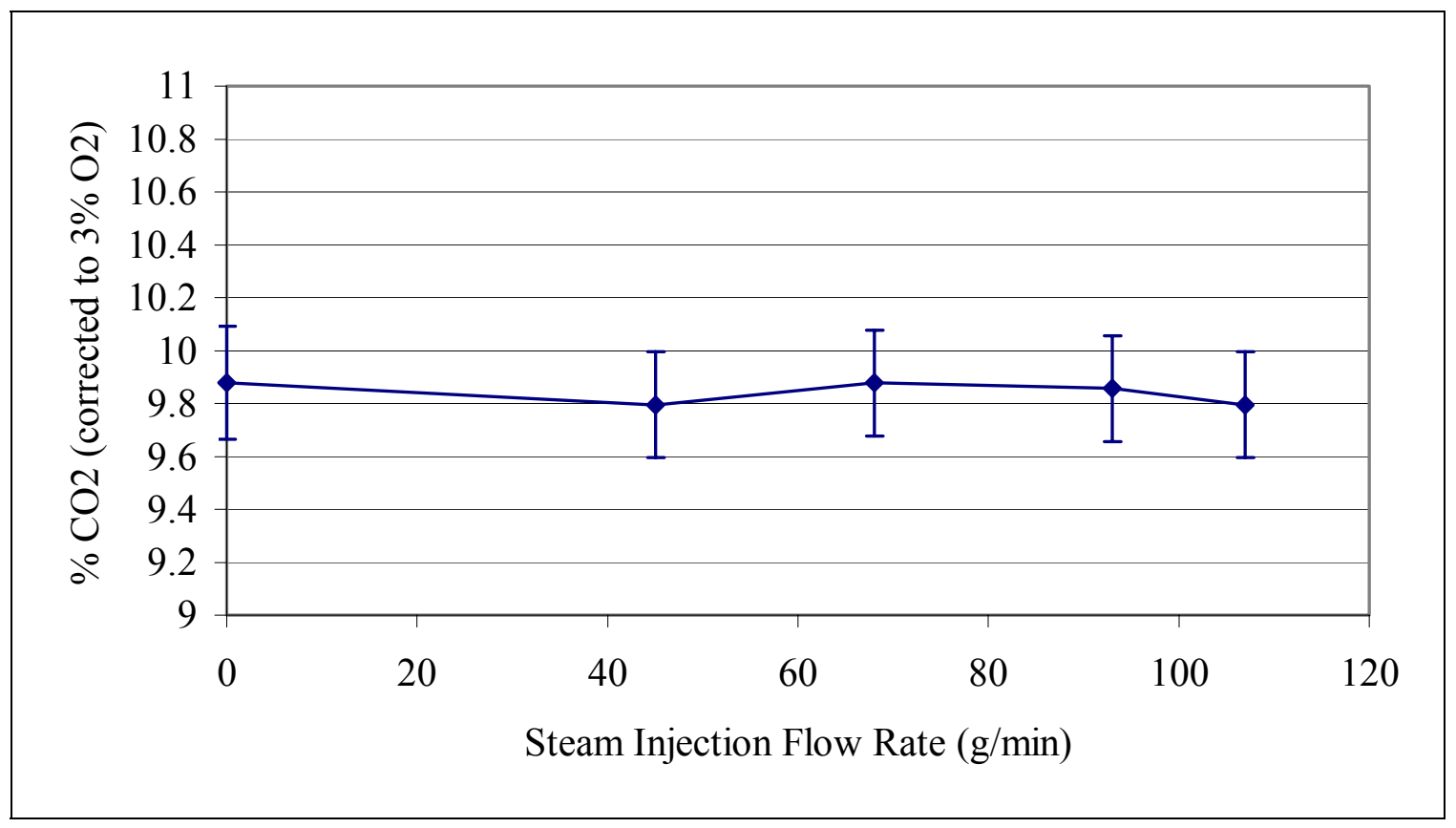

Figure 15. Effect of steam injection on the $\mathrm{CO}_{2}$ concentration measured at the exhaust.

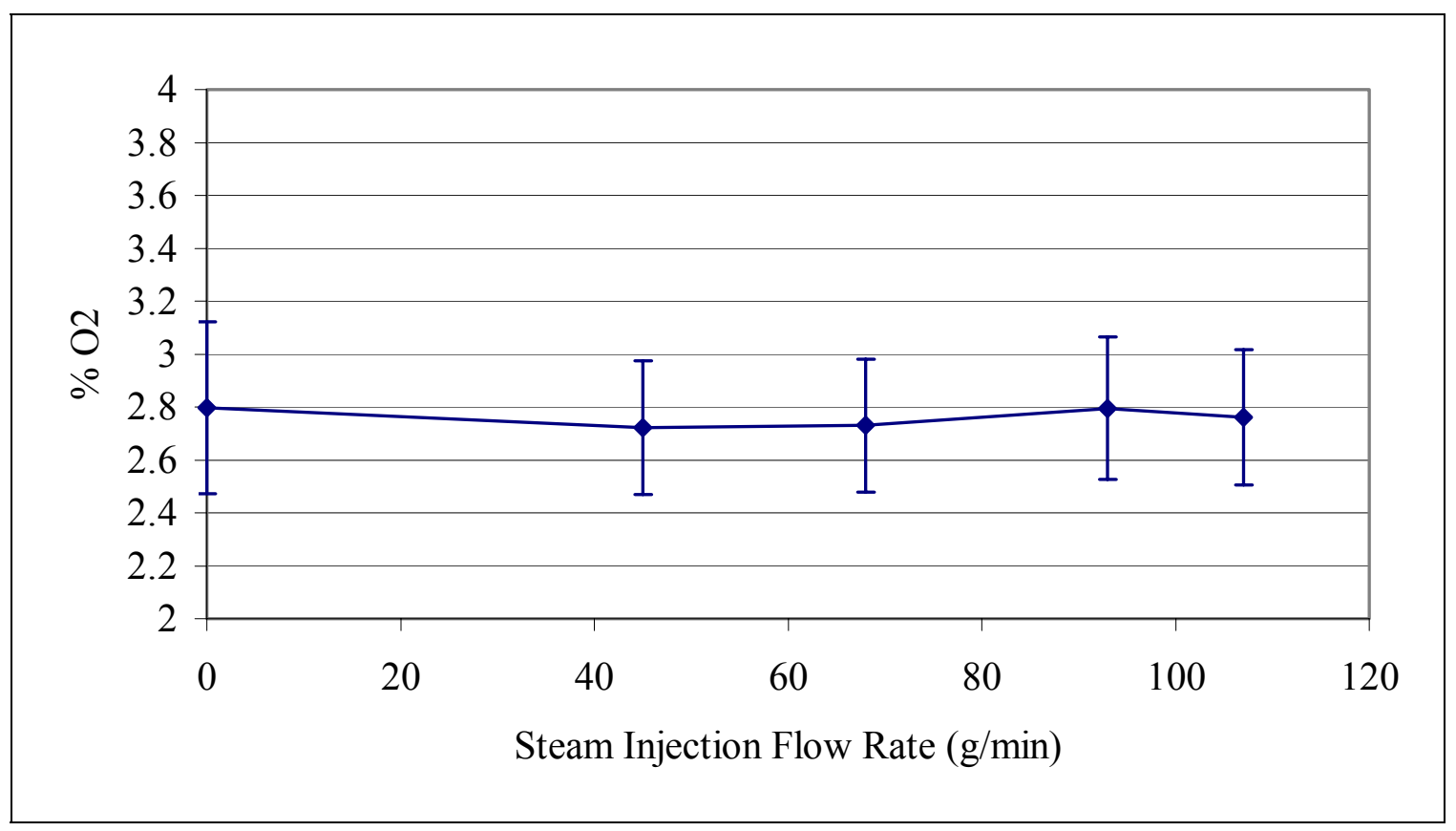

Figure 16. Effect of steam injection on the $\mathrm{O}_{2}$ concentration measured at the exhaust. 


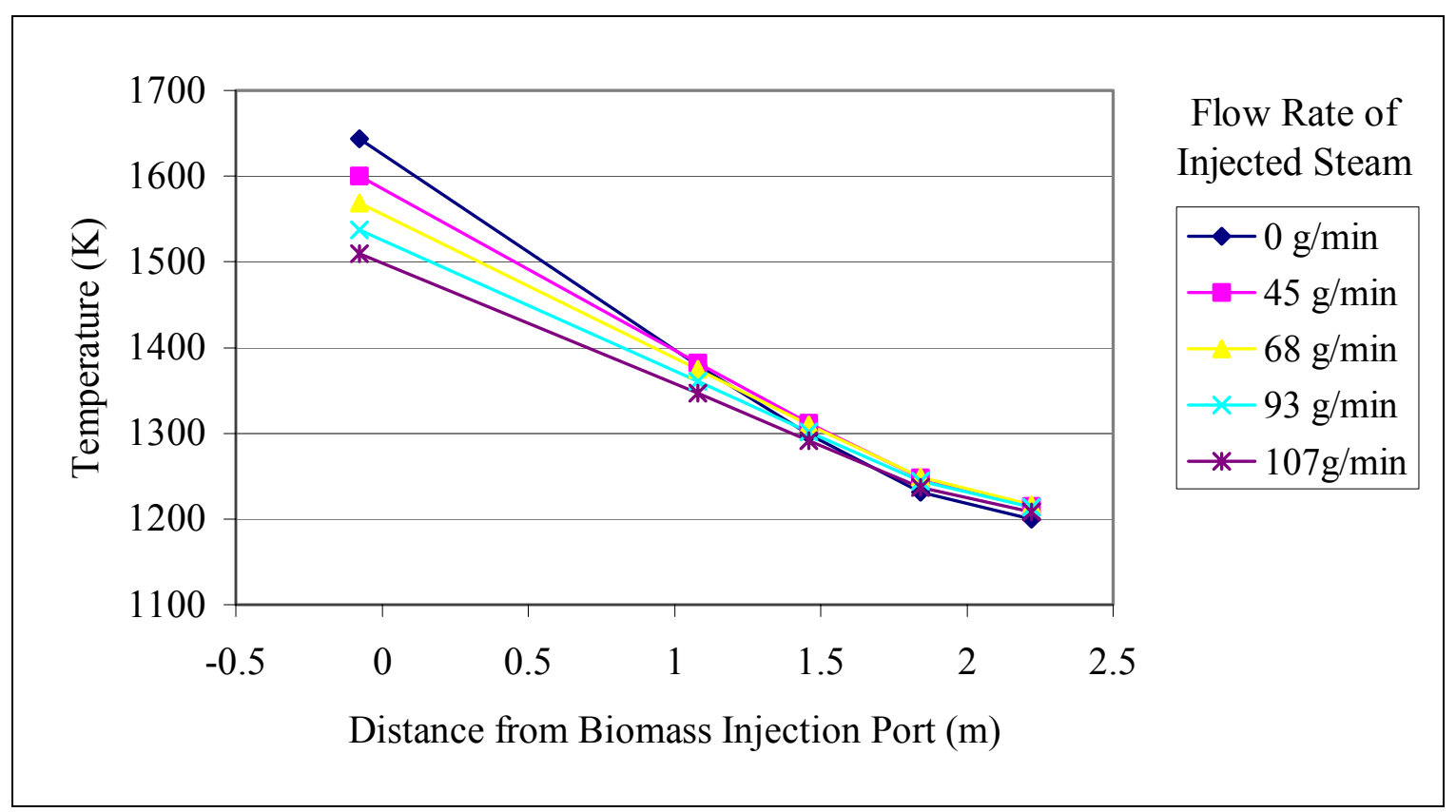

Figure 17. Axial temperature profiles vs. distance downstream from the biomass injection port.

Additional experiments with steam demonstrated that the steam flow rate was either unstable or inappropriate for the reburning experiments performed in the laboratory. If a low flow rate of steam was employed, the steam would often cool sufficiently that it would condense in the plumbing, even though it had been superheated by the throttling process. To prevent condensation, the plumbing would have to be heated or a higher flow rate of steam would be required to keep the plumbing hot. Figure 17 indicates that the higher flow rates of steam significantly impact the axial temperature profile. Attempts to keep the steam super heated by electrically heating the plumbing downstream of the metering valve where the steam had been throttle were unsuccessful. When steam was used as the only biomass carrier gas, the biomass would clog in a matter of minutes because when the steam came in contact with the room temperature, dry biomass, the steam condensed and was absorbed by the biomass like a sponge. Combinations of steam and nitrogen were tried, but with similar results. Another issue was the amount of steam required to physically transport the biomass in this particular laboratory environment required a much higher mass flow rate of steam than that which would be consumed if the biomass were gasified in situ and allowed to react to form hydrogen by the water-gas shift mechanism, as in Equation 1.

$$
\mathrm{CO}+\mathrm{H}_{2} \mathrm{O} \leftrightarrow \mathrm{H}_{2}+\mathrm{CO}_{2}
$$

$\mathrm{CO}$ would come from the gasification of the biomass, and the $\mathrm{H}_{2} \mathrm{O}$ would come from the steam, and the $\mathrm{H}_{2}$ would take part in the reburning process.[3] A 50:50 mixture by mass of steam and biomass would be sufficient to generate hydrogen, but such a mixture was deemed impractical in this small-scale laboratory setting. A larger-scale installation would fare better because the steam could possibly be superheated more effectively, or the plumbing would be larger relative to the biomass particles, or different injection system could be employed.

Steam was also tried as an additive, with a different plumbing configuration, as shown in Figure 5. With this plumbing configuration, nitrogen was the primary carrier gas, and steam was 
added to the nitrogen/biomass stream as it entered the reactor. After fifteen minutes of operation, barely enough time to achieve steady-state and not enough time to collect any meaningful data, the biomass would clog inside the flange shown in Figure 5.

\section{Carbon Dioxide Tracer Experiments}

Table 3 lists the four carbon dioxide tracer experiments that were performed to determine if there was an axial concentration gradient, which would indicate slow mixing of the carbon dioxide with the bulk flow. Both hot and ambient temperature tests were performed. For the ambient temperature tests, the Reynolds number could be controlled because the temperature inside the reactor is constant, resulting in a constant kinematic viscosity and volumetric flow rate throughout the reactor. Two different flow rates of air were used to give two different Reynolds numbers. These Reynolds numbers represent the estimated upper and lower values of the flue gas when the reactor is operating at full power. When the reactor is running under full power, the Reynolds number varies within the reactor because the volumetric flow rate and kinematic viscosity are temperature dependent. Also, unlike the ambient temperature experiments, there is carbon dioxide in the flue gas prior to carbon dioxide injection, so a baseline had to be established for the hot experiment.

Figures 18 and 19 show the results of the $\mathrm{CO}_{2}$ tracer experiments, performed to determine if there was sufficient mixing of the injected biomass and the flue gas inside the down-flow reactor. Figure 18 are the results for the room temperature condition, and Figure 19 are the results for when the reactor is at full power. The calculated $\mathrm{CO}_{2}$ concentrations were determined by performing a mass balance using a set flow rate of $\mathrm{CO}_{2}$. Instantaneous radial mixing is assumed for these calculations, and any variations of the calculated concentrations are due to fluctuations of the primary air flow rate. The same flow rate of $\mathrm{CO}_{2}$ was used for both Reynolds numbers. From Figure 18, it can be stated that, within the statistical precision of the experiment, the measured concentration of $\mathrm{CO}_{2}$ is the same as the calculated concentration, indicating fast radial dispersion of the $\mathrm{CO}_{2}$ in the air stream. There is no change in concentration axially, which could indicated there the mixing is completed upstream of the first sampling port, or that there might be axial dispersion.

At room temperature conditions, the residence time is greater between the biomass injection port and the sampling ports because of the lower volumetric flow rate, so there would be more time for the $\mathrm{CO}_{2}$ to mix with the air. The experiment was repeated when the reactor was running at full power, at $4 \% \mathrm{O}_{2}$, and consequently at a shorter residence time. In Figure 19 the baseline concentrations were measured because unlike in the previous experiment, there was already some $\mathrm{CO}_{2}$ present due to combustion of natural gas. The calculated values were made by assuming complete combustion of natural gas, and instantaneous radial dispersion, with any variations of the calculated values are due to fluctuations of the gas and primary air flow rates. Though the calculated values and the measured values do not correspond as closely as in Figure 18 , there is no statistically significant difference between them, indicating again that the $\mathrm{CO}_{2}$ mixed fast with the flue gas. There is also no apparent axial concentration profile of $\mathrm{CO}_{2}$. As mentioned above, this could be due to either complete mixing of the flue gas and the $\mathrm{CO}_{2}$ upstream of the first sampling port, or due to axial dispersion. Axial dispersion in a tubular reactor would represent a continously well-stirred reactor, but well-stirred reactors do not have temperature gradients, so it is determined that there is no axial dispersion of the $\mathrm{CO}_{2}$. From these four experiments it was determined that there was sufficient mixing of $\mathrm{CO}_{2}$ and flue gas, so 
there would be sufficient mixing of biomass and flue gas as well, even at these relatively low Reynolds numbers.

Table 3. Carbon dioxide tracer experiments test matrix.

\begin{tabular}{|c|c|c|c|c|}
\hline Experiment & Environment & $\begin{array}{c}\text { Reynolds } \\
\text { Number }\end{array}$ & $\begin{array}{c}\text { Primary Air } \\
\text { Flow Rate } \\
\text { liter / min }\end{array}$ & $\begin{array}{c}\text { Carbon Dioxide } \\
\text { Flow Rate } \\
\text { liter / min }\end{array}$ \\
\hline 9 & $\begin{array}{c}\text { Ambient } \\
\text { Temperature }\end{array}$ & $\begin{array}{c}2900 \text { (estimated } \\
\text { lower value) }\end{array}$ & 345 & 16.9 \\
\hline 10 & $\begin{array}{c}\text { Ambient } \\
\text { Temperature }\end{array}$ & $\begin{array}{c}4300 \text { (estimate } \\
\text { upper value) }\end{array}$ & 515 & 16.9 \\
\hline 11 & $\begin{array}{c}\text { Reactor } \\
\text { Operating } \\
\text { at } 35 \mathrm{~kW}\end{array}$ & $\begin{array}{c}\text { Varies within } \\
\text { Reactor } \\
2900-4300\end{array}$ & & 21.1 \\
\hline 12 & $\begin{array}{c}\text { Reactor } \\
\text { Operating } \\
\text { at } 35 \mathrm{~kW}\end{array}$ & $\begin{array}{c}\text { Varies within } \\
\text { Reactor } \\
2900-4300\end{array}$ & & 0 \\
\hline
\end{tabular}

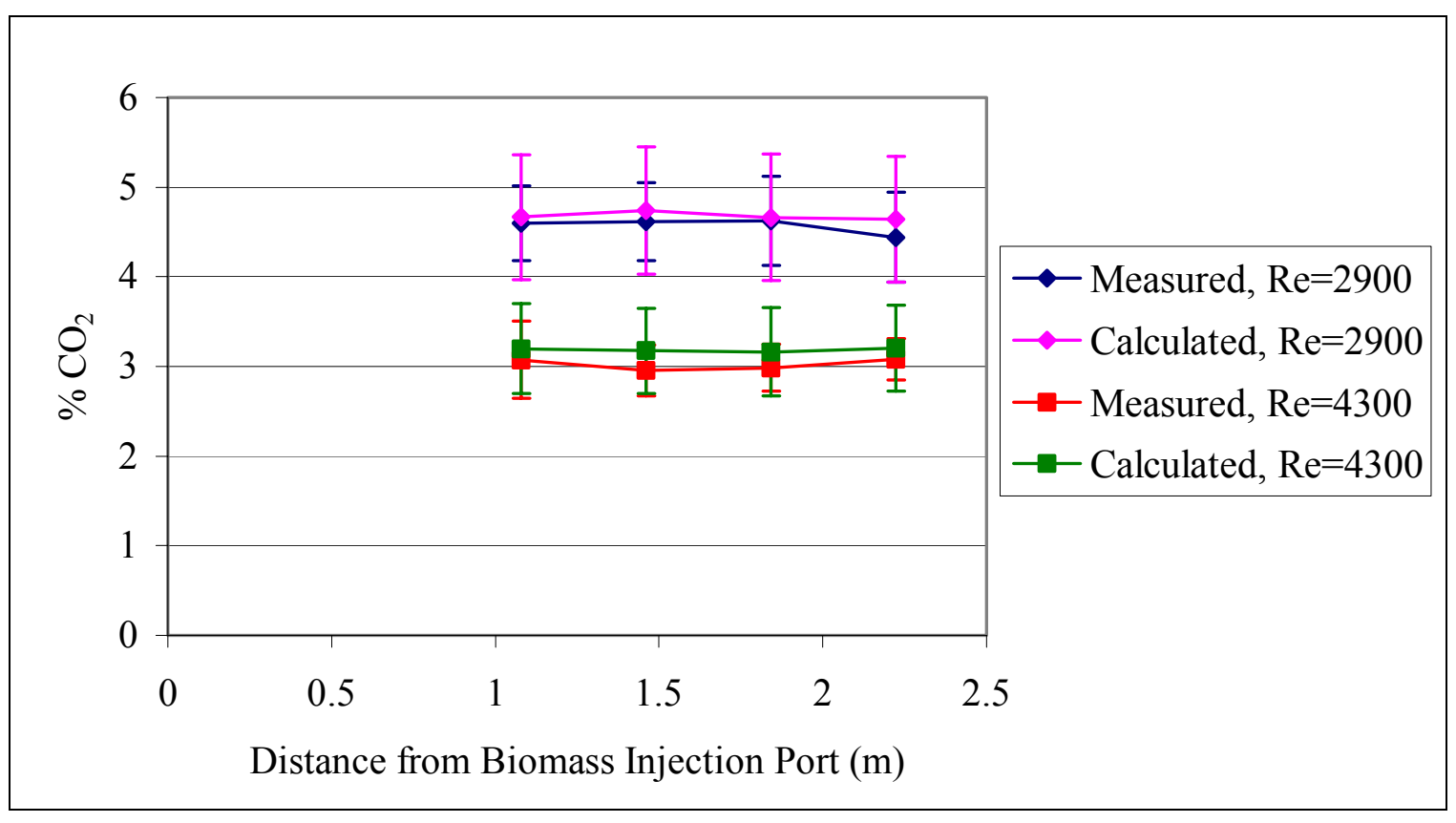

Figure 18. Room temperature $\mathrm{CO}_{2}$ tracer experiments. Measured and calculated axial $\mathrm{CO}_{2}$ concentration profiles. 


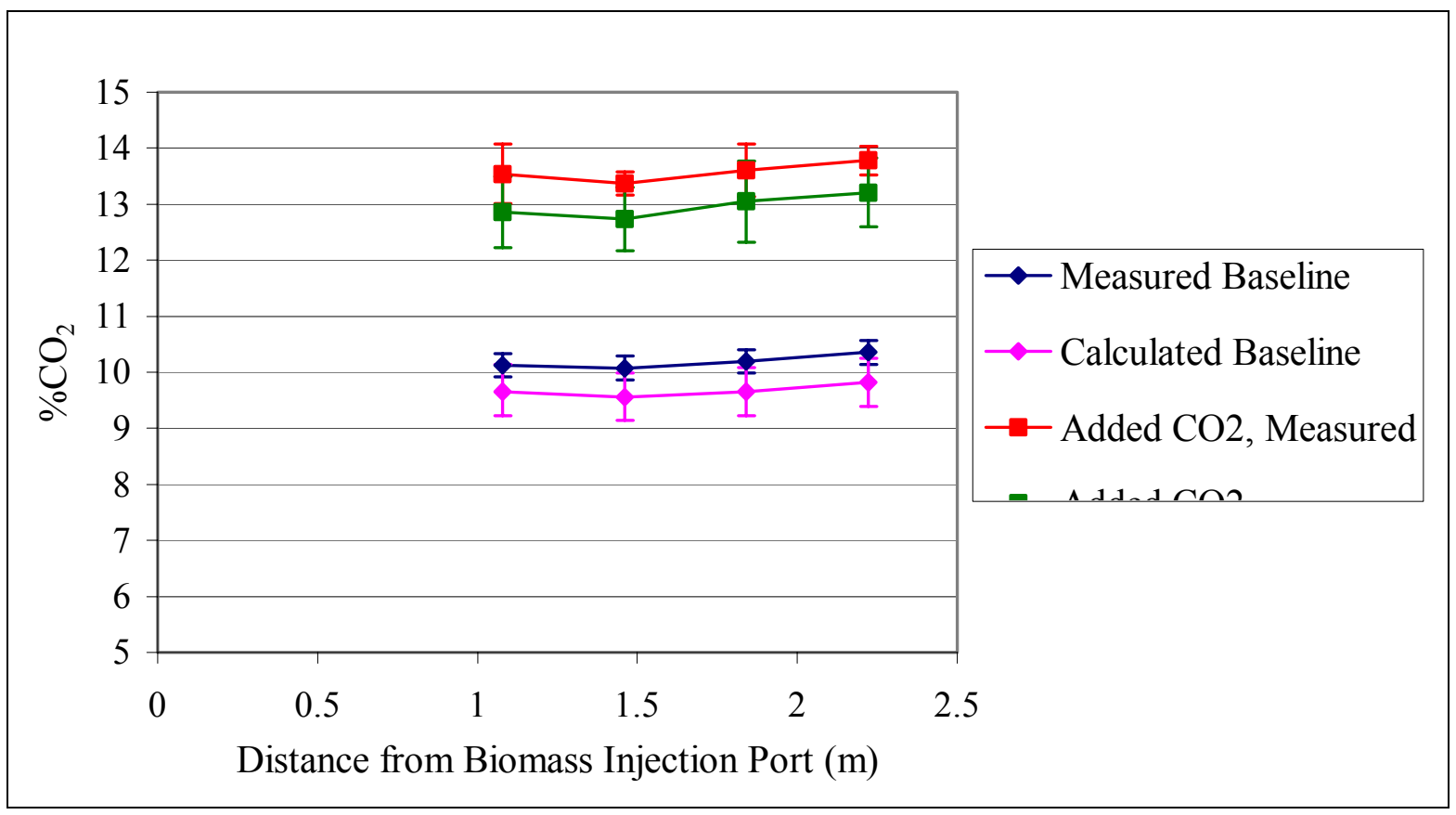

Figure 19. $\mathrm{CO}_{2}$ tracer experiments when reactor is running at full power. Measured and calculated axial $\mathrm{CO}_{2}$ concentration profiles.

\section{Fuel-Lean Biomass Reburning Experiments}

Table 4 is the list of reburn experiments that were performed using switchgrass as the reburn fuel. In all experiments, 47.2 liters/min (100 scfh) of nitrogen was used as the carrier gas. The initial oxygen concentration varied from $1.14 \%-3.93 \%$ by volume for simulated pulverized coal boilers (Experiments 13 - 37) and 4.91\% and 6.35\% (Experiments $38-51$ ) for simulated stoker boilers. The initial $\mathrm{NO}_{\mathrm{x}}$ concentration, corrected to $3 \% \mathrm{O}_{2}$, was $507 \pm 33 \mathrm{ppm}$. The $\%$ energy input from biomass varied from $0.0 \%-19.3 \%$.

Table 5 is the list of reburn experiments that were performed using alfalfa as the reburn fuel. 47.2 liters/min (100 SCFH) of nitrogen was used as the carrier gas. The initial oxygen concentration varied from $1.05 \%-3.96 \%$ by volume for simulated pulverized coal boilers (Experiments $52-73$ ) and 4.91\% and 6.35\% (Experiments $74-85$ ) for simulated stoker boilers. The initial $\mathrm{NO}_{\mathrm{x}}$ concentration, corrected to $3 \% \mathrm{O}_{2}$, was $502 \pm 38 \mathrm{ppm}$. The $\%$ energy input from biomass varied from $0.0 \%-23.0 \%$. 
Table 4. Switchgrass reburn experiments test matrix.

\begin{tabular}{|c|c|c|c|}
\hline Experiment & $\begin{array}{c}\text { Initial Oxygen } \\
\text { Concentration } \\
(\% \text { vol. })\end{array}$ & $\begin{array}{c}\text { Switchgrass } \\
\text { Flow Rate } \\
\text { (gm / min) }\end{array}$ & $\begin{array}{l}\text { Energy Input From } \\
\text { Switchgrass }\end{array}$ \\
\hline 13 & $1.14 \%$ & 0 & $0.0 \%$ \\
\hline 14 & $1.14 \%$ & 5.5 & $4.2 \%$ \\
\hline 15 & $1.14 \%$ & 9.1 & $6.7 \%$ \\
\hline 16 & $1.14 \%$ & 12.6 & $9.1 \%$ \\
\hline 17 & $1.14 \%$ & 16.2 & $11.3 \%$ \\
\hline 18 & $1.73 \%$ & 0 & $0.0 \%$ \\
\hline 19 & $1.73 \%$ & 5.5 & $4.2 \%$ \\
\hline 20 & $1.73 \%$ & 9.1 & $6.7 \%$ \\
\hline 21 & $1.73 \%$ & 12.6 & $9.1 \%$ \\
\hline 22 & $2.94 \%$ & 0 & $0.0 \%$ \\
\hline 23 & $2.94 \%$ & 5.5 & $4.2 \%$ \\
\hline 24 & $2.94 \%$ & 9.1 & $6.7 \%$ \\
\hline 25 & $2.94 \%$ & 12.6 & $9.1 \%$ \\
\hline 26 & $2.94 \%$ & 16.2 & $11.3 \%$ \\
\hline 27 & $2.94 \%$ & 19.7 & $13.5 \%$ \\
\hline 28 & $2.94 \%$ & 23.3 & $15.5 \%$ \\
\hline 29 & $3.93 \%$ & 0 & $0.0 \%$ \\
\hline 30 & $3.93 \%$ & 5.5 & $4.2 \%$ \\
\hline 31 & $3.93 \%$ & 9.1 & $6.7 \%$ \\
\hline 32 & $3.93 \%$ & 12.6 & $9.1 \%$ \\
\hline 33 & $3.93 \%$ & 16.2 & $11.3 \%$ \\
\hline 34 & $3.93 \%$ & 19.7 & $13.5 \%$ \\
\hline 35 & $3.93 \%$ & 23.3 & $15.5 \%$ \\
\hline 36 & $3.93 \%$ & 26.9 & $17.5 \%$ \\
\hline 37 & $3.93 \%$ & 30.4 & $19.3 \%$ \\
\hline 38 & $4.91 \%$ & 0 & $0.0 \%$ \\
\hline 39 & $4.91 \%$ & 5.5 & $4.2 \%$ \\
\hline 40 & $4.91 \%$ & 9.1 & $6.7 \%$ \\
\hline 41 & $4.91 \%$ & 12.6 & $9.1 \%$ \\
\hline 42 & $4.91 \%$ & 16.2 & $11.3 \%$ \\
\hline 43 & $4.91 \%$ & 19.7 & $13.5 \%$ \\
\hline 44 & $4.91 \%$ & 23.3 & $15.5 \%$ \\
\hline 45 & $6.35 \%$ & 0 & $0.0 \%$ \\
\hline 46 & $6.35 \%$ & 5.5 & $4.2 \%$ \\
\hline 47 & $6.35 \%$ & 9.1 & $6.7 \%$ \\
\hline 48 & $6.35 \%$ & 12.6 & $9.1 \%$ \\
\hline 49 & $6.35 \%$ & 16.2 & $11.3 \%$ \\
\hline 50 & $6.35 \%$ & 19.7 & $13.5 \%$ \\
\hline 51 & $6.35 \%$ & 23.3 & $15.5 \%$ \\
\hline
\end{tabular}


Table 5. Alfalfa reburn experiments test matrix.

\begin{tabular}{|c|c|c|c|}
\hline Experiment & $\begin{array}{c}\text { Initial Oxygen } \\
\text { Concentration } \\
\text { (\% vol.) }\end{array}$ & $\begin{array}{l}\text { Alfalfa Flow Rate } \\
\text { (gm / min) }\end{array}$ & $\begin{array}{l}\text { \% Energy Input } \\
\text { From Alfalfa }\end{array}$ \\
\hline 52 & $1.05 \%$ & 0.0 & $0.0 \%$ \\
\hline 53 & $1.05 \%$ & 6.6 & $6.7 \%$ \\
\hline 54 & $1.05 \%$ & 14.3 & $10.5 \%$ \\
\hline 55 & $1.05 \%$ & 21.6 & $14.0 \%$ \\
\hline 56 & $2.06 \%$ & 0.0 & $0.0 \%$ \\
\hline 57 & $2.06 \%$ & 6.6 & $6.7 \%$ \\
\hline 58 & $2.06 \%$ & 14.3 & $10.5 \%$ \\
\hline 59 & $2.06 \%$ & 21.6 & $14.0 \%$ \\
\hline 60 & $2.06 \%$ & 27.5 & $17.2 \%$ \\
\hline 61 & $3.07 \%$ & 0.0 & $0.0 \%$ \\
\hline 62 & $3.07 \%$ & 6.6 & $6.7 \%$ \\
\hline 63 & $3.07 \%$ & 14.3 & $10.5 \%$ \\
\hline 64 & $3.07 \%$ & 21.6 & $14.0 \%$ \\
\hline 65 & $3.07 \%$ & 27.5 & $17.2 \%$ \\
\hline 66 & $3.07 \%$ & 31.6 & $20.2 \%$ \\
\hline 67 & $3.96 \%$ & 0.0 & $0.0 \%$ \\
\hline 68 & $3.96 \%$ & 6.6 & $6.7 \%$ \\
\hline 69 & $3.96 \%$ & 14.3 & $10.5 \%$ \\
\hline 70 & $3.96 \%$ & 21.6 & $14.0 \%$ \\
\hline 71 & $3.96 \%$ & 27.5 & $17.2 \%$ \\
\hline 72 & $3.96 \%$ & 31.6 & $20.2 \%$ \\
\hline 73 & $3.96 \%$ & 37.9 & $23.0 \%$ \\
\hline 74 & $4.91 \%$ & 0.0 & $0.0 \%$ \\
\hline 75 & $4.91 \%$ & 6.6 & $6.7 \%$ \\
\hline 76 & $4.91 \%$ & 14.3 & $10.5 \%$ \\
\hline 77 & $4.91 \%$ & 21.6 & $14.0 \%$ \\
\hline 78 & $4.91 \%$ & 27.5 & $17.2 \%$ \\
\hline 79 & $4.91 \%$ & 31.6 & $20.2 \%$ \\
\hline 80 & $6.35 \%$ & 0.0 & $0.0 \%$ \\
\hline 81 & $6.35 \%$ & 6.6 & $6.7 \%$ \\
\hline 82 & $6.35 \%$ & 14.3 & $10.5 \%$ \\
\hline 83 & $6.35 \%$ & 21.6 & $14.0 \%$ \\
\hline 84 & $6.35 \%$ & 27.5 & $17.2 \%$ \\
\hline 85 & $6.35 \%$ & 31.6 & $20.2 \%$ \\
\hline
\end{tabular}

Figures 20 and 21 compare the final $\mathrm{NO}_{\mathrm{x}}$ concentrations using switchgrass and alfalfa as reburn fuels. For an initial $\mathrm{O}_{2}$ concentration of $1 \%$, both biomasses reduced $\mathrm{NO}_{\mathrm{x}}$. However, switchgrass injection reduces $\mathrm{NO}_{\mathrm{x}}$ concentrations for $2 \%, 3 \%$, and $4 \% \mathrm{O}_{2}$, while alfalfa injection generates $\mathrm{NO}_{\mathrm{x}}$ until more than $12 \%$ of the energy input is from alfalfa for $2 \% \mathrm{O}_{2}$ and more than $17 \%$ of the energy input is from alfalfa for $3 \% \mathrm{O}_{2}$. For the stoker boiler simulations when the 
reactor operated at $5 \%$ and $6 \% \mathrm{O}_{2}$, switchgrass injection had no effect on the $\mathrm{NO}_{\mathrm{x}}$ concentration, but alfalfa injection increased the $\mathrm{NO}_{\mathrm{x}}$ concentration. The desired effect of amine-enhancement was not achieved, rather it was determined that the fuel-bound nitrogen in the alfalfa was being oxidized.

Figures 22 and 23 compare the $\% \mathrm{NO}_{\mathrm{x}}$ reduction using switchgrass and alfalfa as reburn fuels. As described earlier for Figures 20 and 21, switchgrass was an effective reburn fuel, while alfalfa generated $\mathrm{NO}_{\mathrm{x}}$.

Figures 24 and 25 compare the final $\mathrm{CO}$ concentrations using switchgrass and alfalfa as reburn fuels. Significantly less CO was produced by alfalfa injection than by switchgrass injection. No appreciable quantities of $\mathrm{CO}$ were formed under the very fuel lean conditions of $5 \%$ and $6 \% \mathrm{O}_{2}$. The large error bars are due to unsteady biomass injection, which is a result of the pulsating nature of the biomass-metering auger. From Figures 22 and 26, one can estimate the best $\mathrm{NO}_{\mathrm{x}}$ reduction while maintaining low $\mathrm{CO}$ emissions is $20 \%-25 \%$ when operating at $11 \%$ energy input from switchgrass for $3 \% \mathrm{O}_{2}$ in the flue gas to $16 \%$ energy input for $4 \% \mathrm{O}_{2}$ in the flue gas.

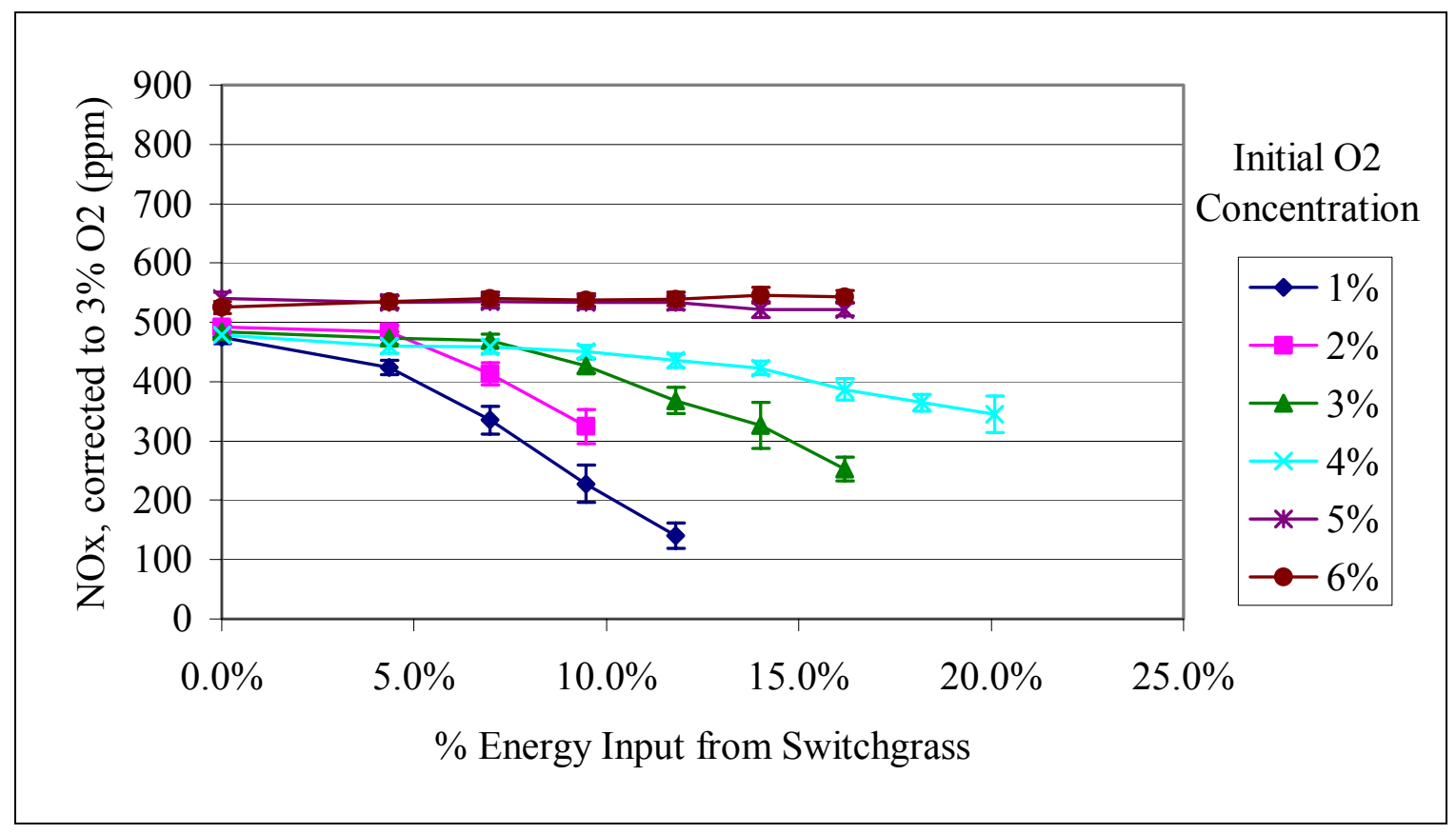

Figure 20. Final $\mathrm{NO}_{\mathrm{x}}$ concentrations vs. \% energy input from switchgrass. 


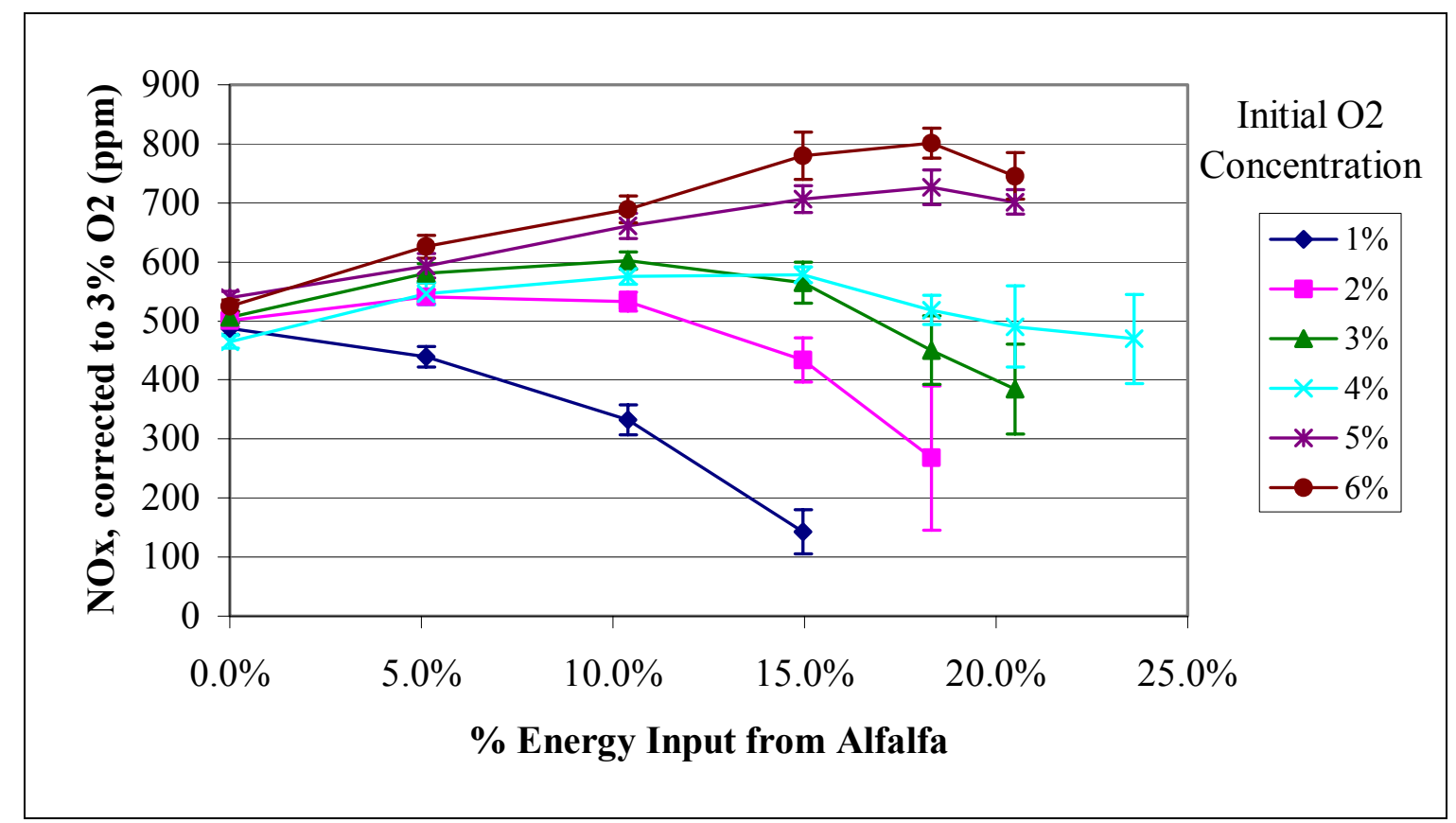

Figure 21. Final $\mathrm{NO}_{\mathrm{x}}$ concentrations vs. \% energy input from alfalfa.

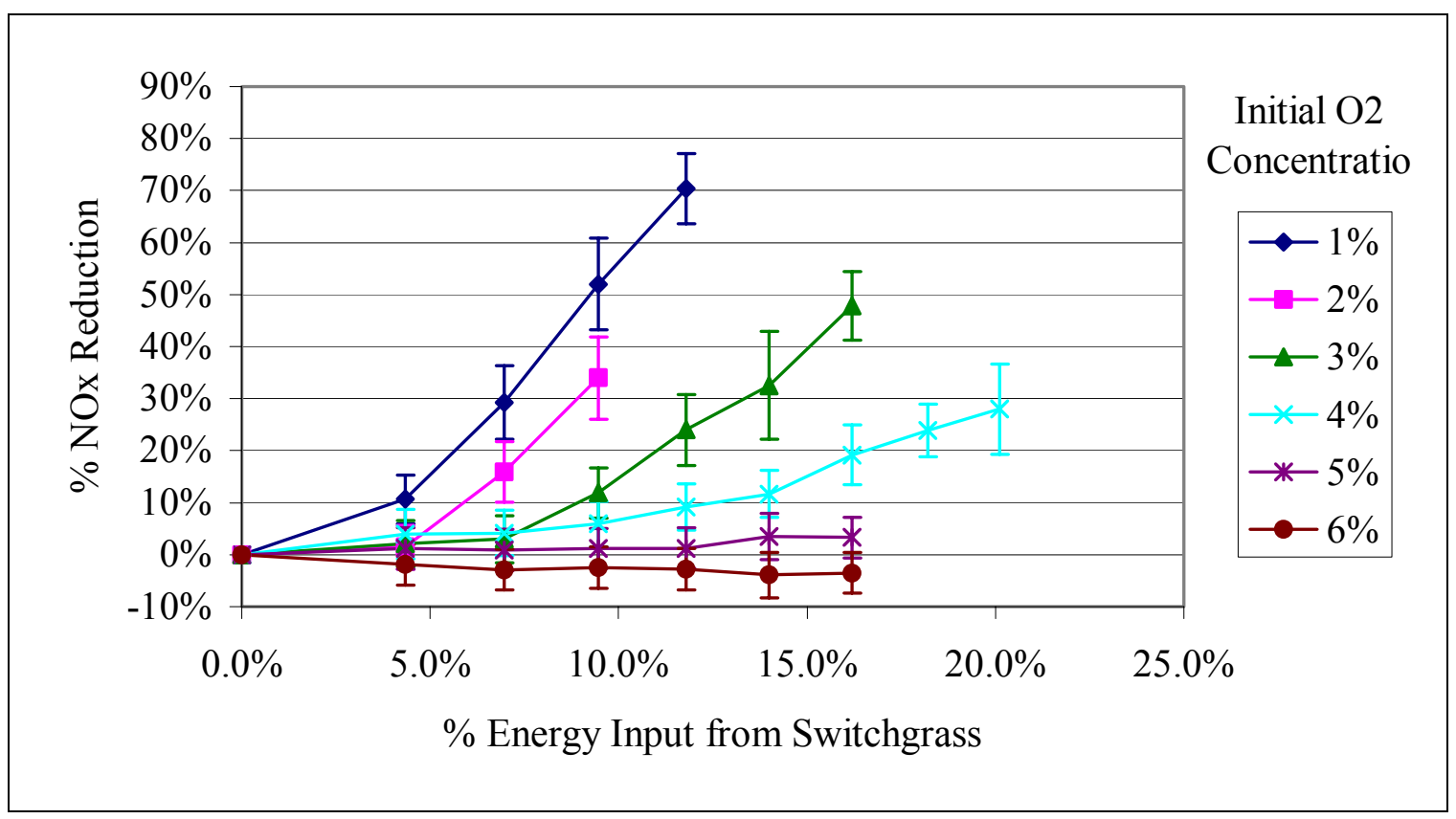

Figure 22. $\% \mathrm{NO}_{\mathrm{x}}$ reduction vs. \% energy input from switchgrass. Negative values indicate $\mathrm{NO}_{\mathrm{x}}$ generation. 


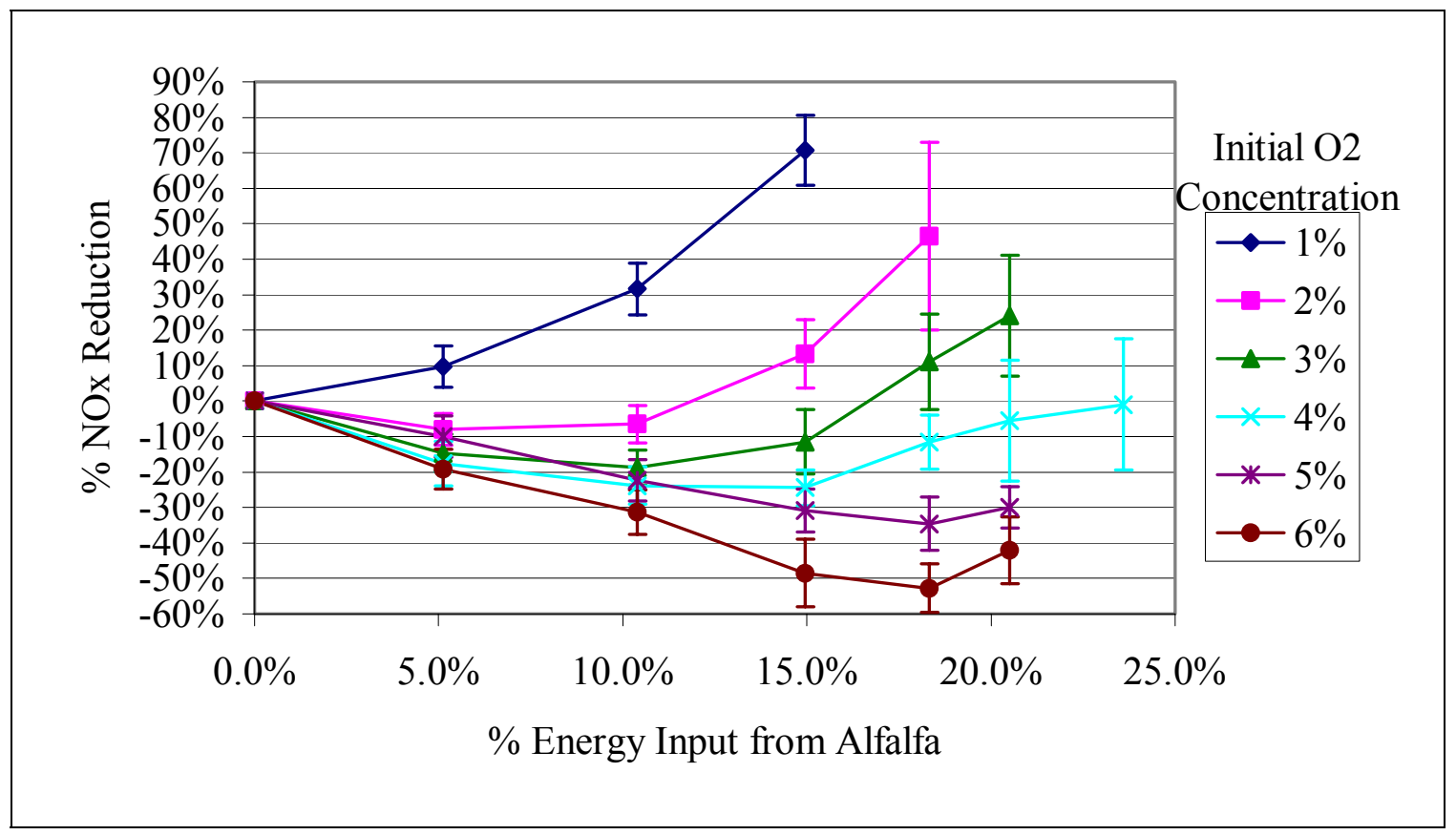

Figure $23 . \% \mathrm{NO}_{\mathrm{x}}$ reduction vs. $\%$ energy input from alfalfa for different initial $\mathrm{O}_{2}$ concentrations. Negative values indicate $\mathrm{NO}_{\mathrm{x}}$ generation.

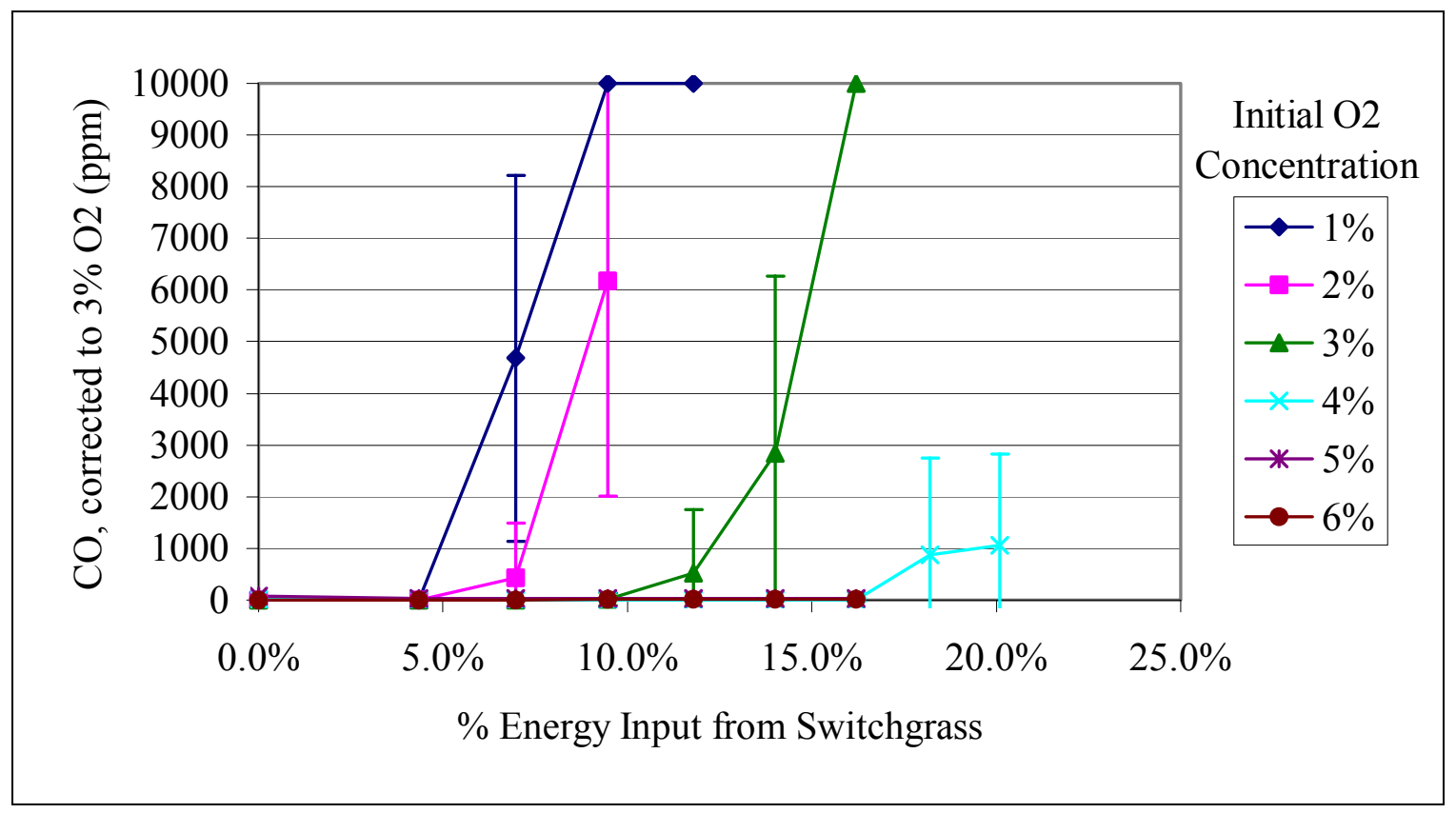

Figure 24. Final CO concentrations vs. \% energy input from switchgrass. 


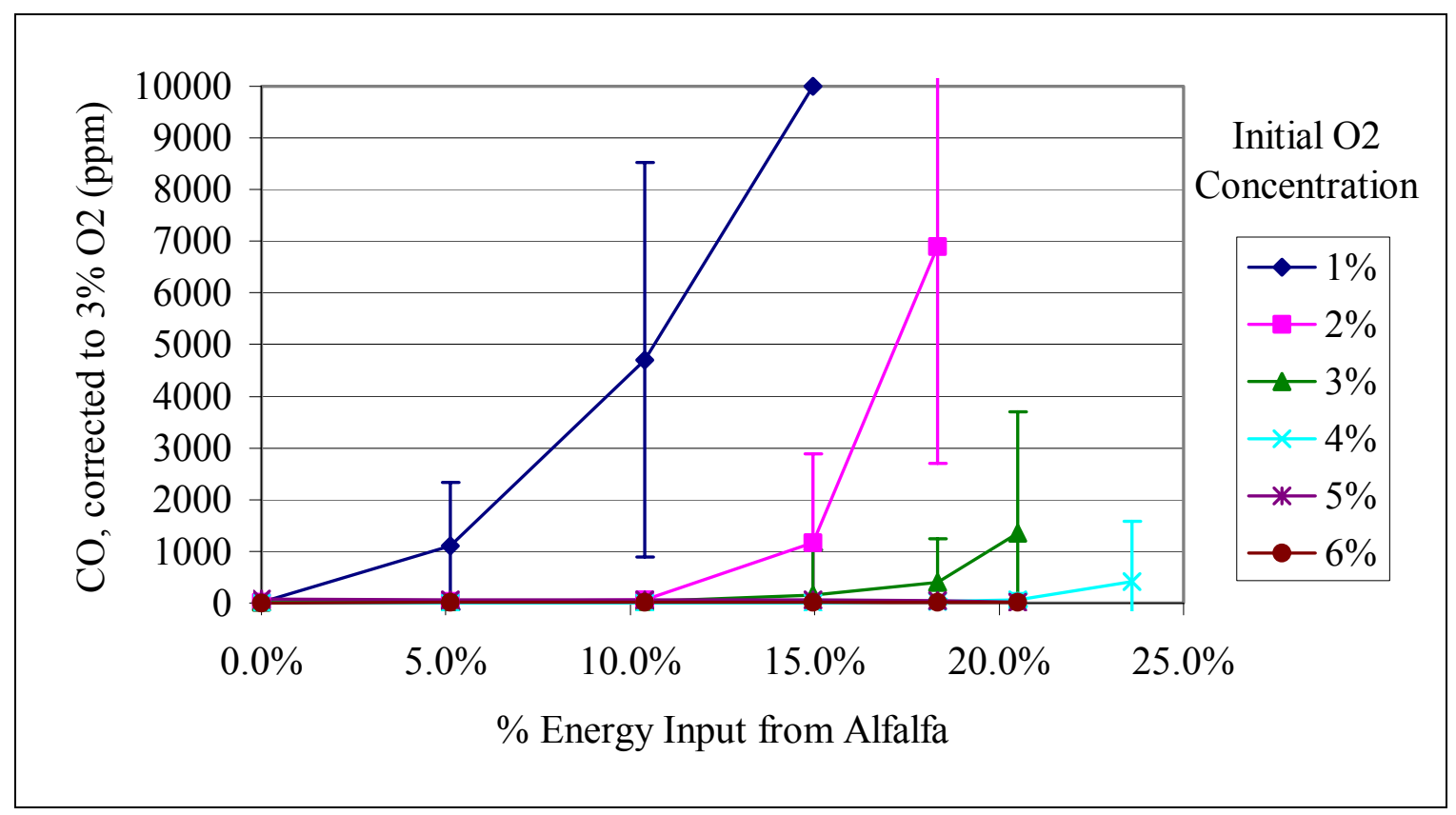

Figure 25. Final $\mathrm{CO}$ concentrations vs. \% energy input from alfalfa.

Figures $26-28$ are representative temperature profiles in the down-flow reactor for initial concentrations of $1 \%, 3 \%$, and $6 \% \mathrm{O}_{2}$ using switchgrass as the reburn fuel. Figure 26 shows the addition of biomass does not significantly increase the temperature at the point of injection, and the temperature downstream increases marginally when operating with an initial $\mathrm{O}_{2}$ concentration of $1 \%$. The reactor becomes fuel rich, limiting how much energy can be obtained from the combustion of biomass because the combustion is incomplete.

Figure 27 shows the addition of biomass increases the temperature when operating with an initial $\mathrm{O}_{2}$ concentration of $3 \%$. More energy is released from the addition of switchgrass because there is sufficient oxygen to react with it. The baseline temperature, $0 \%$ Energy Input from Switchgrass, is lower than for the $1 \% \mathrm{O}_{2}$ experiments.

To obtain an initial $\mathrm{O}_{2}$ concentration of $6 \%$, the mass flow rate of air was $22 \%$ higher than the $3 \% \quad \mathrm{O}_{2}$ operating condition while maintaining a constant natural gas flow rate. Comparatively, to obtain an initial $\mathrm{O}_{2}$ concentration of $3 \%$, the mass flow rate of air was only $11 \%$ higher than the $1 \% \mathrm{O}_{2}$ operating condition, with a constant flow rate of natural gas. Figure 28 shows that because of this high flow rate of air for the $6 \% \mathrm{O}_{2}$ operating condition (and a higher flow rate of flue gas), the addition of biomass has less of an effect on temperature profiles. The baseline temperatures are much lower than for the previous two figures, and the temperature profiles are less steep which indicates that the gas stream is cooling at a slower rate. Temperature profiles for alfalfa were similar. 


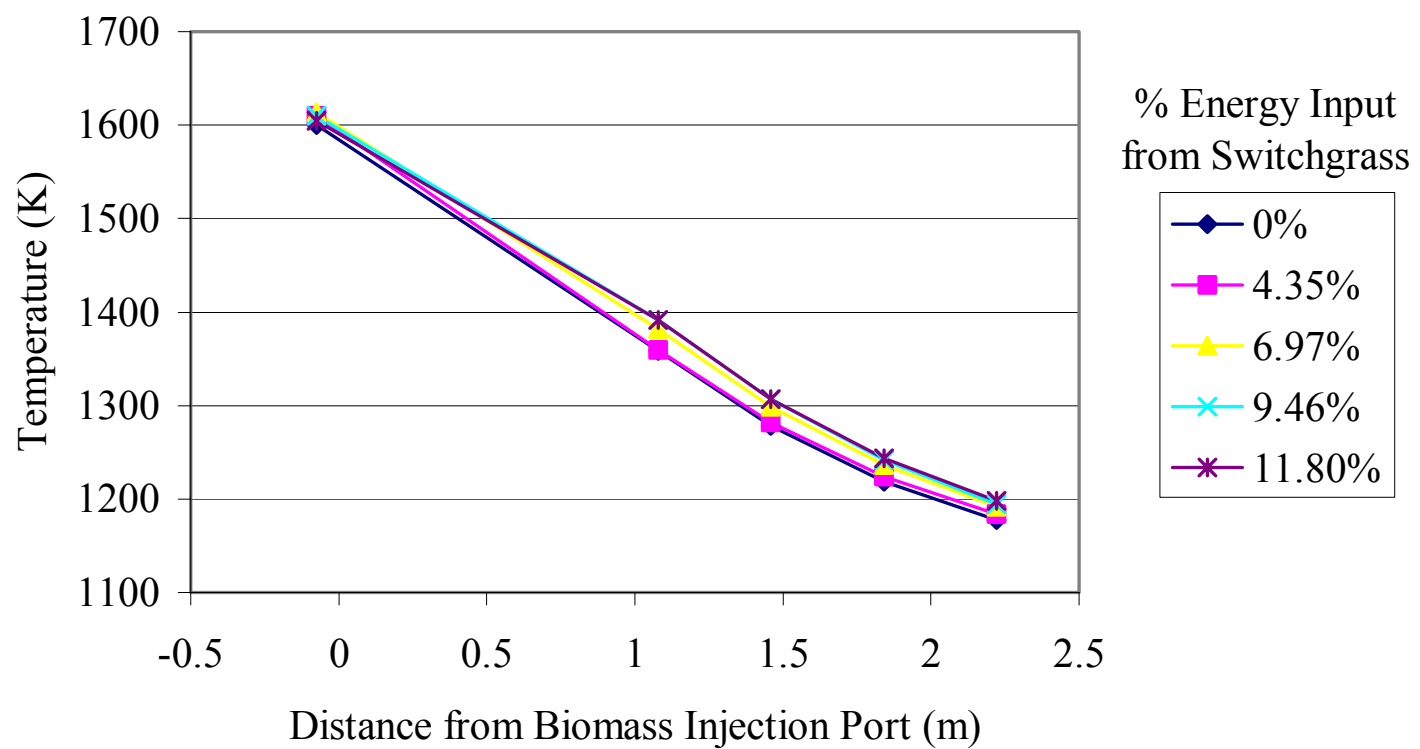

Figure 26. Axial temperature. Distance is downstream from biomass injection port. $1 \%$ initial $\mathrm{O}_{2}$.

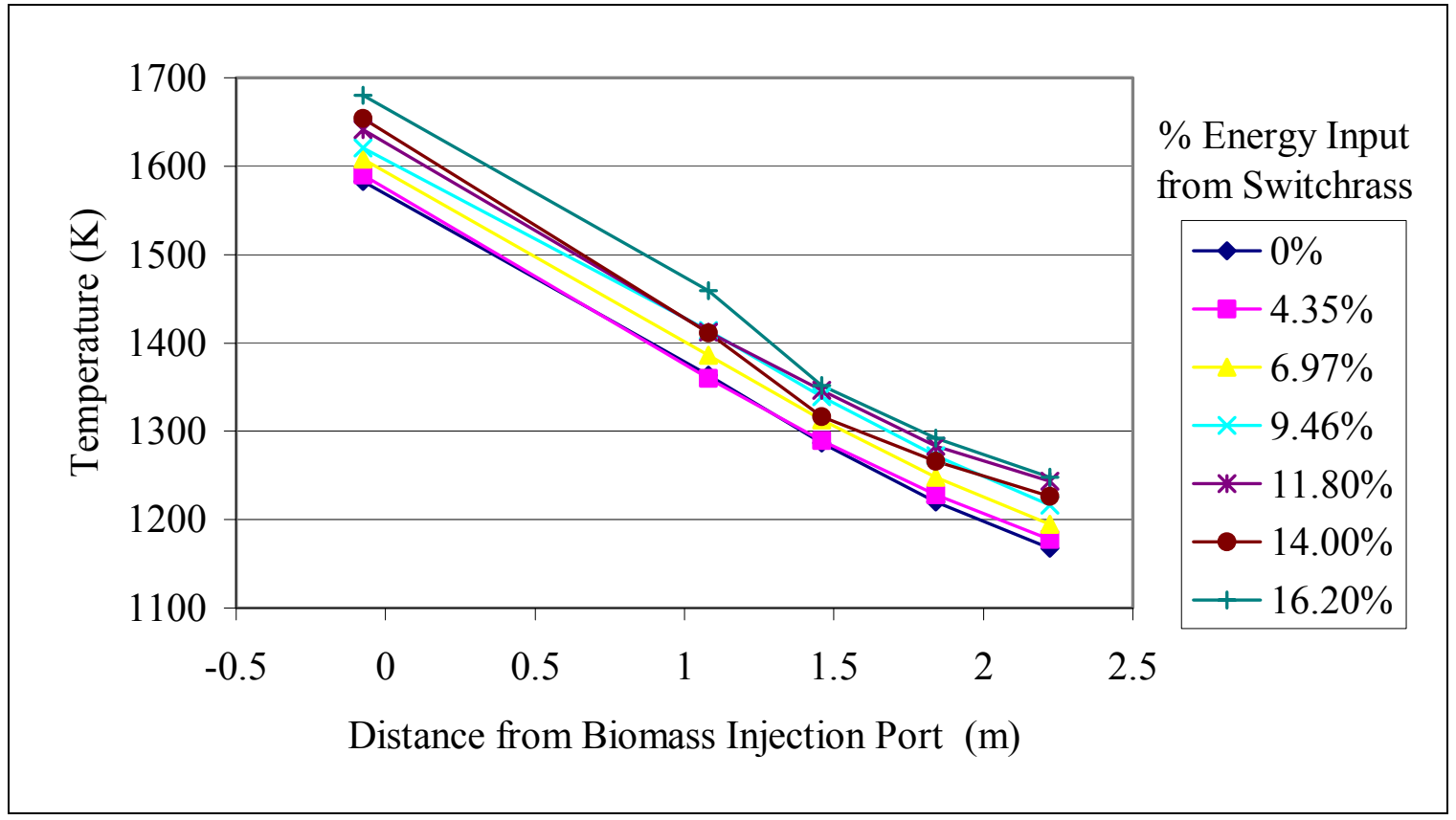

Figure 27. Axial temperature profiles. Distance is downstream from biomass injection port. $3 \%$ Initial $\mathrm{O}_{2}$. 


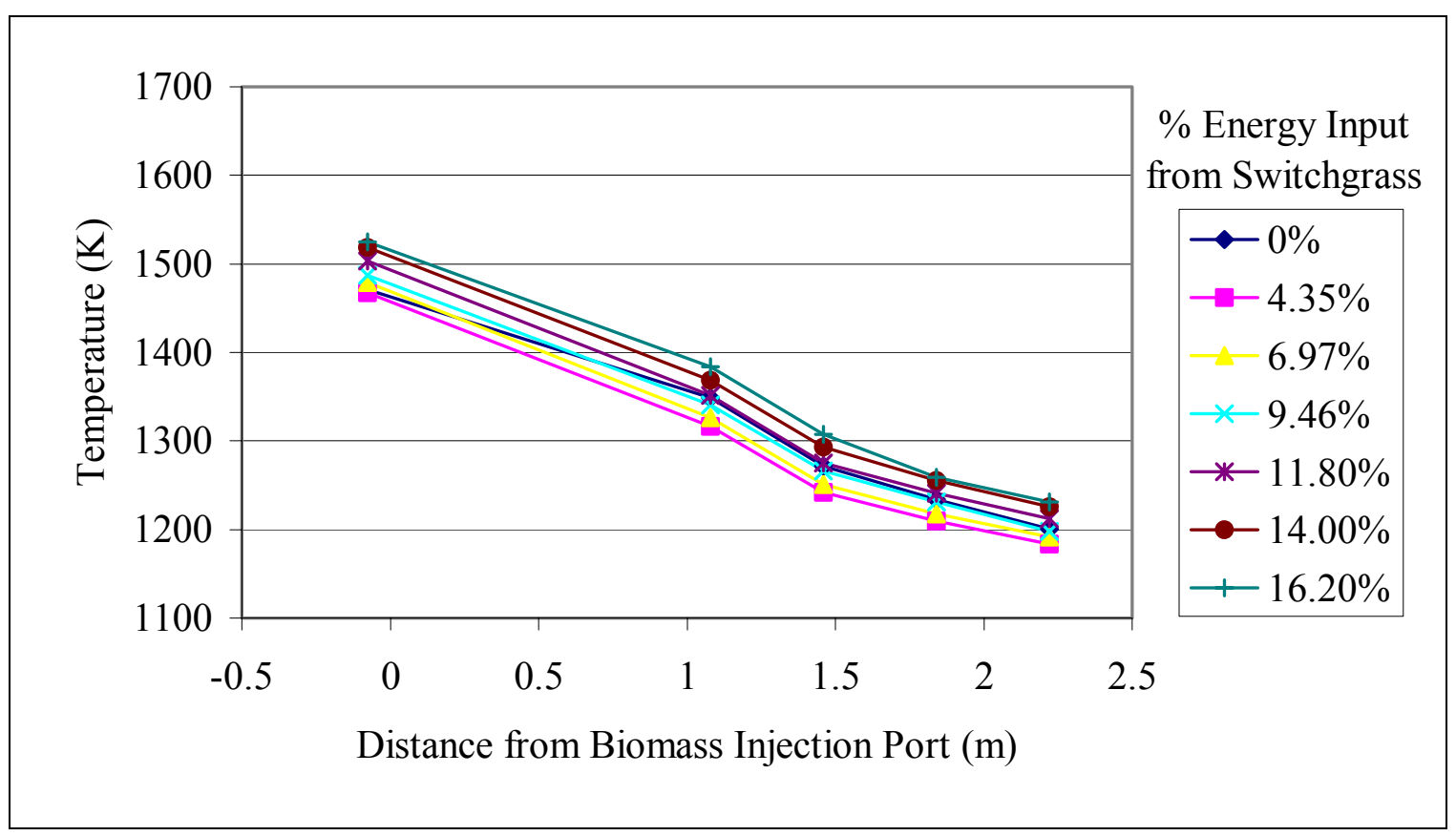

Figure 28. Axial temperature profiles. Distance is downstream from biomass injection port. $6 \%$ initial $\mathrm{O}_{2}$.

\section{ECONOMIC ANALYSIS [3]}

Biomass injection with steam was not successful at the small scale of the laboratory. A larger-scale installation would fare better because the steam could possibly be superheated more effectively, or the plumbing would be larger relative to the biomass particles, or different injection system could be employed. The economic analysis assumes that biomass can be successfully injected with steam as the carrier fluid in a full-scale installation.

The commercialization of Fuel-Lean Biomass Reburning will depend upon the achievement of economically beneficial nitric oxide reductions in a large-scale pulverized coal fired boiler. Nitric oxide reductions of $25 \%$ to $40 \%$ or greater would need to be demonstrated on $100 \mathrm{MW}$ to 300 MW capacity utility boiler while capital and operating costs are established. Adverse operating effects must be taken into account and ameliorated. Operating characteristics that must be continuously evaluated are unit heat rate efficiency, unburned carbon, and manageable boiler depositions along with minimal impact on other operating conditions of the boiler. In order to be economically beneficial the cost of a ton of nitric oxide reduced should not exceed $\$ 2,000 /$ ton. This is a cost which is competitive with Low $\mathrm{NO}_{\mathrm{x}}$ Burners (LNB) and Selective Non-Catalytic Reduction (SNCR), and is much lower in cost than Selective Catalytic Reduction (SCR).

The capital cost of a completely installed and operating Fuel-Lean Biomass Water Reburn System is presented in Table 6, including developmental/research costs associated with a first of a kind demonstration. The installed and operating Fuel-Lean Biomass Reburn $\mathrm{NO}_{\mathrm{x}}$ Reduction System is three million dollars for a $200 \mathrm{MW}$ electric capacity utility boiler, which is equivalent to $\$ 15 / \mathrm{kw}$. 
Table 6. Capital cost of fuel-lean biomass/water reburn equipment and installation.

Basis 200 MW@10\% heat input=200 MMBTU/hr 10 (tons/hr)dry

Bulk Handling

- Bins (switchgrass, alfalfa, stover/tree-bark, sawdust, wood waste/coal/feedlot waste) \$30,000

- Feed Hoppers

$\$ 70,000$

- Conveyors

$\$ 150,000$

$\$ 250,000$

Grinding, Mixing, Suspension and Day Storage

- Feeders

$\$ 200,000$

- Wet Mill with Feed and Output Piping Systems (10 dry ton/hr)

$\$ 800,000$

- Slurry Tanks with Mixing (4 hours capacity/10' dia x 15'

$\$ 100,000$

$\$ 1,100,000$

Pumping, Piping and Control Valves

- Slurry Pumps and Controls

$\$ 30,000$

- Erosion Resistant Piping and Valves

$\$ 170,000$

- Controls, Safety Interlocks \& Firing System

$\$ 100,000$

$\$ 300,000$

Fuel Lean Injection Grind Design

- Computer Furnace Model

$\$ 100,000$

- Injection Grid Options with $\mathrm{NO}_{\mathrm{x}}, \mathrm{O}_{2}$, Carbon Burnout and $\mathrm{CO}$ Calculations

$\$ 150,000$

$\$ 250,000$

Injectors and Firing System

- Furnace Penetrations (10@\$8,000 each)

$\$ 80,000$

- Firing Valves and Individual Flow Control

$\$ 120,000$

- Injectors (10)

$\$ 100,000$

$\$ 300,000$

Engineering and Testing

- Engineering and Construction Management

$\$ 200,000$

- Start-Up and Operational Testing

$\$ 100,000$

- Optimization Testing with Adaptive Process Controller

$\$ 250,000$

- Research Documentation (Spatial CO/NO/O $/ \mathrm{LOI} / \mathrm{T} /$ Trace Elements) and Reporting $\$ \underline{200,000}$

$\$ 750,000$

Total Installed System including Developmental Research

$\$ 2,950,000$

Demonstration of this technology can best be accomplished on a utility boiler within the size range of $100 \mathrm{MW}$ to $300 \mathrm{MW}$ electric production. The basis of cost calculation was chosen as $200 \mathrm{MW}$ because this same size of equipment would be used in larger installations; for example doubling the number of mills or pumps, while smaller size installations may use the approximately same mills, etc. but with smaller motors. 
The operating cost of the biomass fuel injection system can best be presented and evaluated on a basis of $\$ /$ ton of fuel or $\$ / M M B T U$ of fuel delivered, processed and burned. The cost of full in situ gasification of the biomass would require one pound of water per pound of biomass, which results in a $10 \%$ heating value reduction based upon dry heating value of the biomass. With $10 \%$ biomass heat input this water will result in a $1 \%$ heat rate base on total net fuel input or again $10 \%$ based on fuel differential cost of the biomass. At a primary fuel cost of between $\$ 1.00$ and $\$ 2.00$ per MMBTU the gasification steps add $\$ 0.10$ to $\$ 0.20$ as differential cost of gasification per MMBTU of biomass fuel input. The other operating costs are delivered commodity cost and the extra labor in operating handling, milling and firing of the biomass. These are the same operations as required for the primary fuel and on a \$MMBTU basis there should be little differential. For a first time demonstration the total cost my be $50 \%$ to $100 \%$ more than those being experience with the primary fuel. This would be a total differential cost of $\$ 0.50$ to $\$ 1.00 / \mathrm{MMBTU}$.

The total cost of the nitric oxide reduction technology is best compared on the basis of results, that is on the basis of tons of nitric oxide reduced. For the purpose of calculation the tonnage of $\mathrm{NO}_{\mathrm{x}}$ is always evaluated on the basis of $\mathrm{NO}_{2}$. For the experimental research presented in this report, the initial lbs/MMBTU of $\mathrm{NO}_{2}$ for the simulated pulverized coal boiler were estimated to range from $0.52-0.58 \mathrm{lbs} / \mathrm{MMBTU}$, and for the simulated stoker boiler, the initial lbs/MMBTU of $\mathrm{NO}_{2}$ were estimated to range from $0.62-0.74 \mathrm{lbs} / \mathrm{MMBTU}$. The per $\mathrm{kw}$ cost estimate of the $200 \mathrm{MW}$ application plant given in the Equipment and Installation Cost Table 6 is $\$ 15 / \mathrm{kw}$ which with a $25 \%$ contingency would be $\$ 18.50 / \mathrm{kw}$. This would lead to a capital cost per ton of $\$ 700 /$ Ton $\mathrm{NO}_{\mathrm{x}}$ on a basis of only ozone seasonal use of the installed $\mathrm{NO}_{\mathrm{x}}$ reduction system.

Capital Cost (5 months usage per year and 15\% P\&I [Principal and Interest]) $=$ $\$ 700 /$ ton $N O x$ on the basis of $40 \% N O_{x}$ reduction from $0.75 \mathrm{lb} / \mathrm{MMBTU}$

In the event that the starting level of $\mathrm{NO}_{\mathrm{x}}$ emissions were $0.5 \mathrm{lbs} / \mathrm{MMBTU}$ the $40 \%$ reduction would still result in a tonnage cost of $\$ 1,800 /$ Ton which is competitive with $\$ 2,000 /$ Ton technology. Likewise a proven reduction of $33 \%$ would yield a per ton cost of $\$ 1,400 /$ Ton $\mathrm{NO}_{\mathrm{x}}$. Reductions of between $28 \%$ and $40 \%$ with initial $\mathrm{NO}_{\mathrm{x}}$ emissions of above $0.6 \mathrm{lbs} / \mathrm{MMBTU}$ are this economically competitive; at less than $\$ 2,000 /$ Ton $\mathrm{NOx}$ removed. If the initial $\mathrm{NO}_{\mathrm{x}}$ is below $0.6 \mathrm{lbs} / \mathrm{MMBTU}$ then $\mathrm{NO}_{\mathrm{x}}$ reduction of greater than $33 \%$ must be demonstrated. Reductions of $20 \%-25 \%$ were achieved in the current research while maintaining low $\mathrm{CO}$ emissions.

\section{CONCLUSIONS}

Four parameters of Fuel-Lean Biomass Reburning were investigated in this research: the type of carrier gases used to inject the biomass into the down-flow reactor, the initial oxygen concentration, the $\%$ energy input from the reburn fuel, and the type of biomass used.

Both nitrogen and steam were tested as the biomass carrier gas, and neither influenced the baseline chemistry inside the down-flow reactor. Additional experiments demonstrated that there was a lack of precise control of the steam flow rate, resulting in either too much steam or not sufficiently hot steam, and in either case the biomass clogged the plumbing. Nitrogen was a much more consistent carrier gas. 
Mixing experiments demonstrated that even at the relatively low Reynolds numbers achieved in the laboratory, the injected biomass would mix with the flue gas sufficiently to react with $\mathrm{NO}_{\mathrm{x}}$ in the flue gas.

Switchgrass proved to be the better reburn fuel. There appeared to be no amine-enhancement by using higher nitrogen-containing reburn fuel. At low initial $\mathrm{O}_{2}$ concentrations, both switchgrass and alfalfa managed to reduce $\mathrm{NO}_{\mathrm{x}}$ emissions, but produced high $\mathrm{CO}$ emissions. For moderate initial $\mathrm{O}_{2}$ concentrations, $20 \%-25 \% \mathrm{NO}_{\mathrm{x}}$ reduction was possible for switchgrass while maintaining low $\mathrm{CO}$ emissions, but the addition of alfalfa increased the $\mathrm{NO}_{\mathrm{x}}$ concentration due to oxidation of the fuel-bound nitrogen present in alfalfa for most initial $\mathrm{O}_{2}$ concentrations. For high initial $\mathrm{O}_{2}$ concentrations, which were present in the stoker boiler simulations, there was no appreciable effect on the $\mathrm{NO}_{\mathrm{x}}$ concentrations when switchgrass was injected.

An economic evaluation showed that there is potential to install a full-scale biomass injection system if only a slight improvement of $\mathrm{NO}_{\mathrm{x}}$ reduction were possible.

\section{REFERENCES}

[1] Urich, Joseph. Energy Systems Associates, Inc. Personal communication. January 7, 2002.

[2] Schrecengost, R. A., B. P. Breen, A. F. Gomez, A. L. Huhmann, J. M. Pratapas, and R. A. Johnson. "Field Experience Testing Amine Enhanced Fuel Lean Gas Reburn At Public Service Electric \& Gas Mercer Station.” Presented at the 1998 Electric Power Research Institute $\mathrm{NO}_{\mathrm{x}}$ Workshop. Baltimore, MD. August 24-26, 1998.

[3] Breen, Bernard. Energy Systems Associates, Inc. Personal communication. February 1, 2002. 